\title{
Working
}

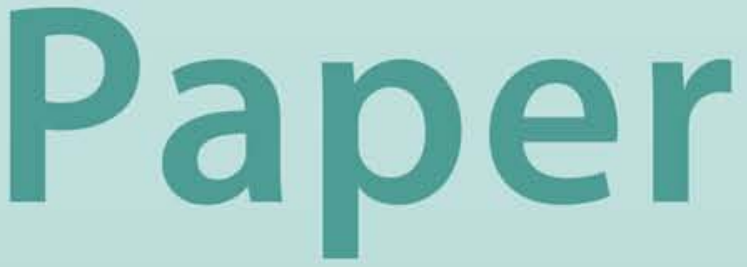


Work Absence in Europe

Leo Bonato and Lusine Lusinyan 


\title{
IMF Working Paper
}

\author{
European Department
}

\section{Work Absence in Europe}

Prepared by Leo Bonato and Lusine Lusinyan ${ }^{1}$

Authorized for distribution by Subhash Thakur

October 2004

\begin{abstract}

\section{This Working Paper should not be reported as representing the views of the IMF.} The views expressed in this Working Paper are those of the author(s) and do not necessarily represent those of the IMF or IMF policy. Working Papers describe research in progress by the author(s) and are published to elicit comments and to further debate.
\end{abstract}

Work absence is an important part of the individual decision on actual working hours. This paper focuses on sickness absence in Europe and develops a stylized model where absence is part of the labor-leisure decision made by workers and the production decision made by profit-maximizing firms, with insurance provisions and labor market institutions affecting the costs of absence. The results from a panel of 18 European countries indicate that absence is increased by generous insurance schemes where employers bear little responsibility for their costs. Shorter working hours reduce absence, but flexible working arrangements are preferable if labor supply erosion is a concern.

JEL Classification Numbers: C23; I18; I38; J22

Keywords: sickness absence; working time; social insurance; panel data; Europe

Author(s) E-Mail Address: 1bonato@imf.org; $\underline{\text { llusinyan@imf.org }}$

\footnotetext{
${ }^{1}$ The authors are with the European Department of the IMF. This paper is an extension of Bonato and Lusinyan (2004), produced in connection with the Article IV Consultation with Sweden. The paper has benefited from comments from Marcello Estevão, Krister Andersson, seminar participants at the Swedish Ministry of Finance, the Institute for Labour Market Policy Evaluation in Uppsala, and IMF headquarters. The authors wish to thank the Eurostat NewCronos LFS team, Lyle Scruggs, and Xavier Debrun for providing different parts of the dataset; Haiyan Shi for excellent research assistance; and Subhash Thakur for his encouragement and advice.
} 


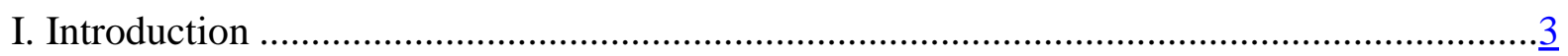

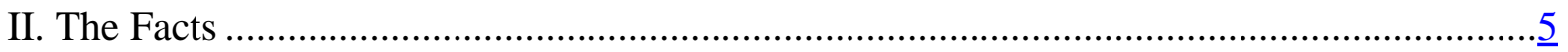

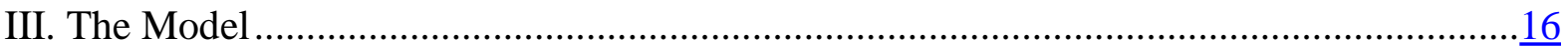

A. Labor Supply (Hours Decision) ……………………………………………16

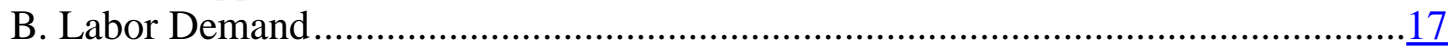

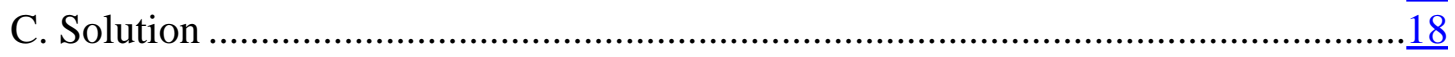

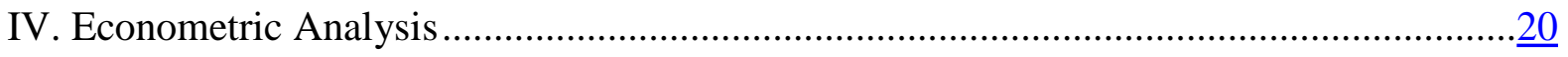

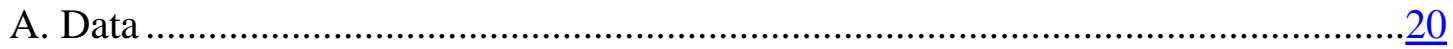

B. Empirical Strategy ……………………………………………………...21

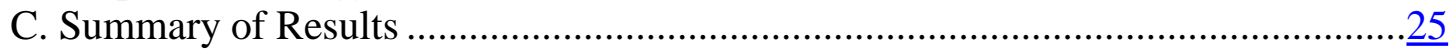

V. Conclusions and Policy Implications .............................................................................26

Tables

1. Sickness Absence in Public and Private Sectors.................................................................. 9

2. Cyclicality of Sickness Absence, 1995-2003 ..................................................................

3. Public Sickness Benefits ....................................................................................

4. Ratio of Sickness Absence of Permanent Workers to Temporary Workers ..........................

5. Determinants of Sickness Absence: Static Panel Data Model.............................................23

6. Determinants of Sickness Absence: Dynamic Panel Data Model ……………………........24

Figures

1. Labor Force Participation Rate and Average Hours Annually Worked Per Employee.......... $\underline{3}$

2. Sickness Absence, Average for 1995-2003 ……………............................................

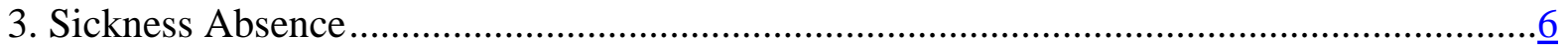

4. Short- and Long-Term Sickness Absence.....................................................................

5. Belgium and Sweden: Short- and Long-Term Sickness Absence ........................................

6. Sickness Absence and Its Determinants ....................................................................11

7. Changes in Sickness Insurance System, 1983-2002 ……............................................

8. Sickness Cash Benefits Paid by Employer ..................................................................

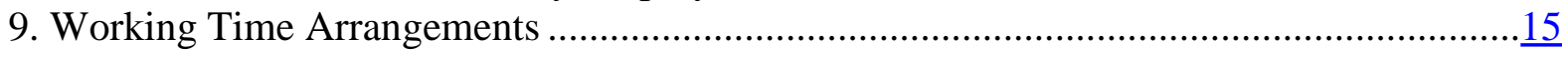

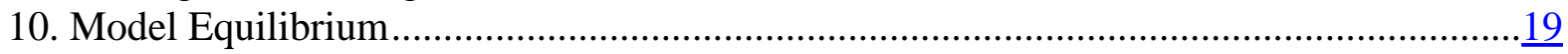

Appendices

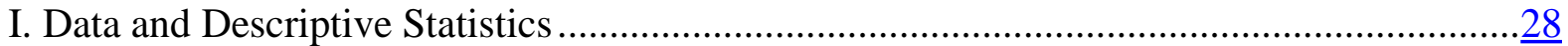

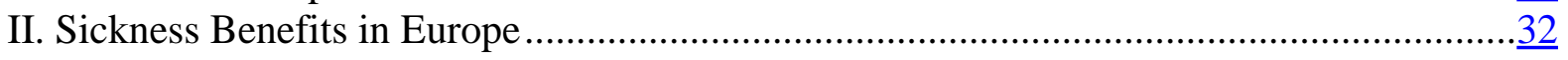

Appendix Tables

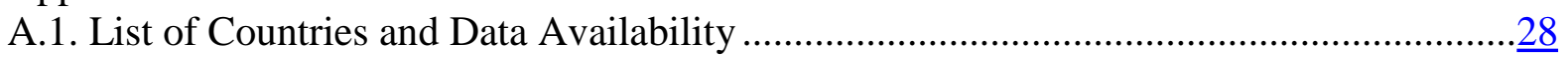

A.2. List of Variables, Definitions, and Sources …………....................................................

A.3. Descriptive Statistics........................................................................................... $\frac{30}{31}$

A.4. Cross-Correlations Between Variables of Model ........................................................

A.5. Comparative Table on Sickness Cash Benefits (as of 01.01.2004) ..................................

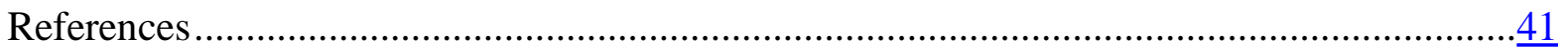




\section{INTRODUCTION}

Low and falling labor utilization has been blamed for the lackluster growth performance of many European countries (OECD, 2003). To a large extent, labor supply erosion can be attributed to the decline in working time. In fact, while participation-possibly owing to labor market reforms - has increased in most European countries in the last twenty years, average working time has continued falling, in line with a long-standing tendency, also common to Japan, but not to the United States or Australia (Figure 1). ${ }^{2}$

Figure 1. Labor Force Participation Rate and Average Hours Annually Worked Per Employee

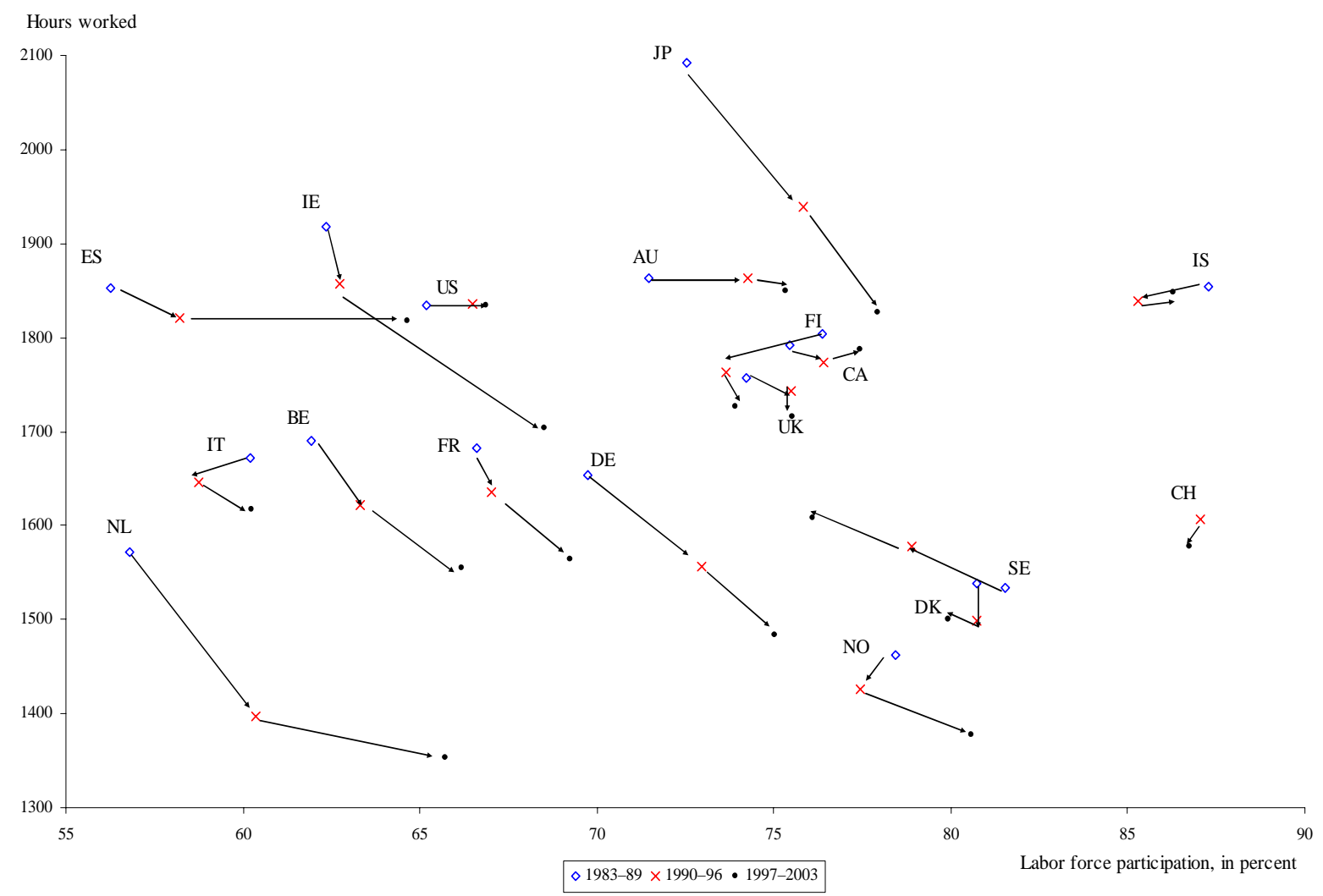

Source: OECD, Economic Outlook.

Notes: $\mathrm{AU}=$ Australia; $\mathrm{BE}=$ Belgium; $\mathrm{CA}=\mathrm{Canada} ; \mathrm{CH}=$ Switzerland; $\mathrm{DE}=$ Germany; $\mathrm{DK}=$ Denmark; $\mathrm{ES}=$ Spain; FI=Finland; FR=France; IE=Ireland; IS=Iceland; IT=Italy; JP=Japan; NL= Netherlands; NO=Norway; SE=Sweden; UK=United Kingdom; US=United States.

Declining hours worked can be a reflection of policies as well as changing preferences. Prescott (2004) finds that differences in the marginal tax rate on labor income can explain most of the historical and cross-country variation in labor supply in the Group of Seven (G-7) countries. Preferences could, however, have also affected the trend of falling working time, which has been a prominent objective of unions in many European countries for some time (Blanchard, 2004). In any case, this trend represents a challenge for European economies in

\footnotetext{
${ }^{2}$ The data on average hours are intended for comparisons of trends over time and are not suitable for comparisons of levels (OECD Employment Outlook, Statistical Annex).
} 
many ways. With a dwindling labor supply, it is not obvious that the current level of potential growth and the financing of large welfare states can be maintained over time. Indeed, the negative consequences for competitiveness are already triggering pressures to change course in France and Germany.

Actual hours worked can be lower because contractual hours are falling or work absence is rising. In Europe, the decline seems to be driven by the reductions in working time negotiated by unions. In 2003, contractual hours ranged from a weekly minimum of 35 hours in France to a maximum of 40 hours in Greece, with most countries having a working week between 37 hours and 39 hours. Over the last five years, the European Union (EU) average (including Norway) has fallen from 38.6 hours to 38 hours. ${ }^{3}$ Looking ahead, the pressure for working time reductions is likely to continue as unions remain committed to this objective.

If national holidays and annual leave - for which country provisions vary widely-are excluded, absence can be accounted for essentially by sickness. On average, absence due to sickness is not unusually high in Europe. In the period 1995-2003, the share of employees on sickness leave was 2.8 percent, on average, which is very close to the 2.6 percent registered in the United States (Figure 2). There are wide differences across countries, however. Absence seems to be particularly high in the Netherlands (6 percent), Sweden (5.2 percent), Norway (5.0 percent) and the United Kingdom (3.9 percent). For these countries, reducing sickness absence could provide a substantial boost to

Figure 2. Sickness Absence, Average for 1995-2003 (as a percentage of employment)

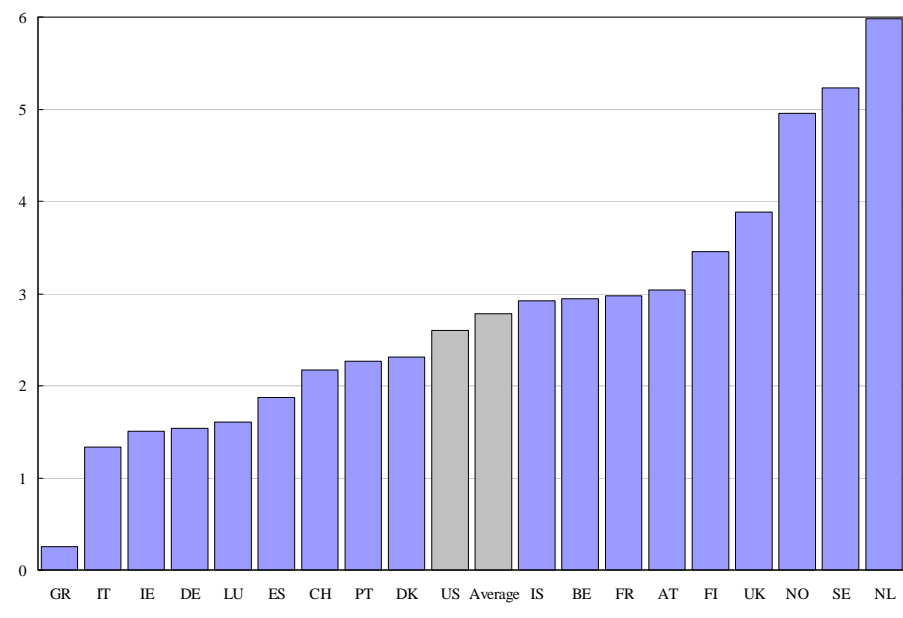

Source: Eurostat, NewCronos.

Notes: $\mathrm{AT}=$ Austria; $\mathrm{BE}=$ Belgium; $\mathrm{CH}=$ Switzerland; $\mathrm{DE}=$ Germany; $\mathrm{DK}=$ Denmark; ES=Spain; FI=Finland; FR=France; GR=Greece; IE=Ireland; IS=Iceland; IT=Italy; LU=Luxembourg; $\mathrm{NL}=$ Netherlands; $\mathrm{NO}=$ Norway; $\mathrm{PT}=$ Portugal; SE=Sweden; UK=United Kingdom; US=United States. the labor supply.

Containing work absence can be beneficial for a number of reasons. Excessive work absence entails significant social and economic costs. In the presence of institutional constraints affecting the choice between work and leisure-such as minimum working hour requirements - absence can be seen as an efficient individual response to the need for flexibility (Dunn and Youngblood, 1986). When absence costs are not internalized by workers, however, significant efficiency costs may arise. Moral hazard may become widespread if insurance is too generous, altering incentives in a way that may not provide the best trade-off between protection and efficiency. Output and employment are likely to be

\footnotetext{
${ }^{3}$ See European Foundation for the Improvement of Living and Working Conditions, European Industrial Relations Observatory.
} 
lower in equilibrium owing to the imperfect substitutability of absent workers. If insurance costs are mainly borne by the government, as is the case in most European countries, significant fiscal costs will also arise.

Theoretical analyses of labor absence and absenteeism mostly focus on labor supply characteristics. Facing a choice between labor supply and leisure, individuals maximize their utility given budget and time constraints (Allen, 1981; Leigh, 1985). Health, age, and gender influence the preference for leisure. If leisure is a normal good, its marginal utility will be decreasing, and the value of an hour of leisure will be higher, the longer is the typical working time. By allowing a more efficient use of the time available, flexible working arrangements are likely to attenuate the preference for leisure. Sickness insurance plays a crucial role. In most countries, the government, the employers, or both provide employees with insurance against the loss of income owing to sickness. With imperfect monitoring, the decision about sick leave is ultimately left to workers, and moral hazard arises. Its impact can be compounded by changing social norms, a weakening work ethic, and a decreasing stigma associated with "benefit cheating" (Lindbeck, 1997). In their decisions about absence, workers face costs in terms of both forgone income, which depend on the generosity of the insurance system, and the possibility of sanctions by the employers, ranging from slow career progression to dismissal.

This paper extends the literature to include labor demand considerations with a role for labor market institutions. The employers' reaction to absence is likely to depend on the costs they have to bear as a result of it. Absence normally involves some output loss, the magnitude of which depends on the firm's technology and workers' heterogeneity. Other costs are related to the characteristics of the insurance scheme. Employers may have to disburse part or all of the cash benefits received by the absentee or pay contributions to the insurance funds. The more costly absence is to the employers, the more likely they are to respond. If absence is clearly connected with the working environment, the employer may attempt to improve it. Otherwise, the employer can increase monitoring or reinforce sanctions for absence. Then labor market institutions come into play. Both employment protection and unemployment insurance reduce the expected cost of work absence to the individual employee either by making it more difficult to sanction absenteeism or by reducing the effective cost of the sanction.

This paper also contributes to the empirical literature by analyzing the determinants of sickness absence on a panel of 18 European countries during the period 1983-2003, using new datasets on sickness insurance provisions and costs to employers. The following section describes the facts regarding sickness absence in Europe. Section III illustrates the model of work absence. Section IV discusses the econometric issues and presents the results from panel data model estimations. Concluding remarks and policy implications follow in Section V.

\section{THE FACTS}

As shown in Figure 2, sickness absence on average is not particularly high in Europe, and the problem seems to be confined to a few countries. Furthermore, Figure 3 shows that sickness absence has been generally stable over the last two decades. There are however some exceptions. In Belgium, for example, sickness absence rate surged from 1 to 4 percent 
between 1990 and 2000. Among the countries with the highest absence rates- the Netherlands, the United Kingdom, Sweden, Norway, and Iceland-Sweden exhibits an upward trend in recent years, while the Netherlands has seen absence declining since 1999. Absence in the United Kingdom has remained broadly stable throughout the period. In most countries, sickness absence is higher for women than for men.

Figure 3. Sickness Absence

(employees absent due to sickness as a percentage of total employed)

(Note the different scale on the vertical axes for the Netherlands, United Kingdom, Sweden, Norway, and Iceland.)
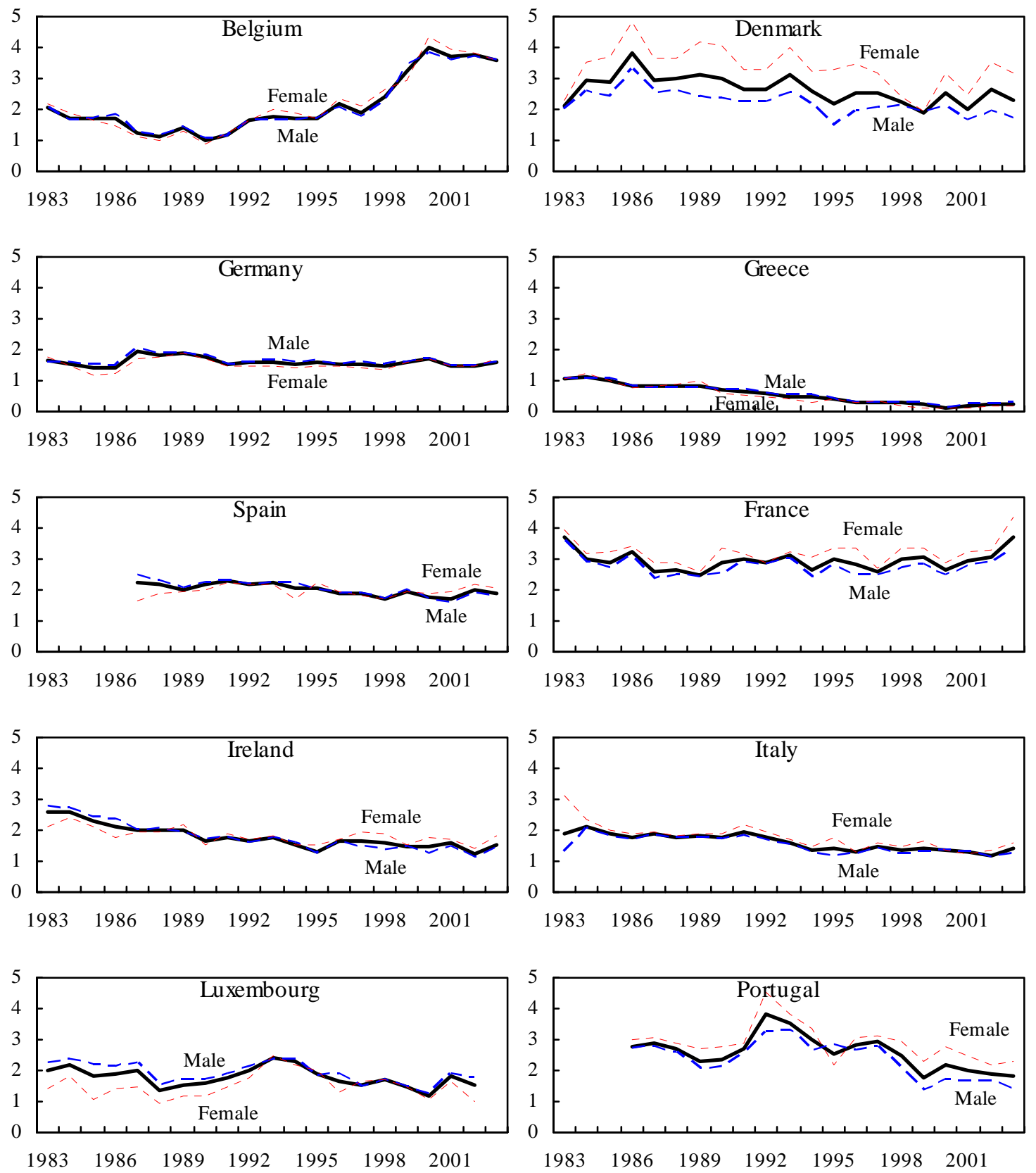
Figure 3. Sickness Absence (Concluded)
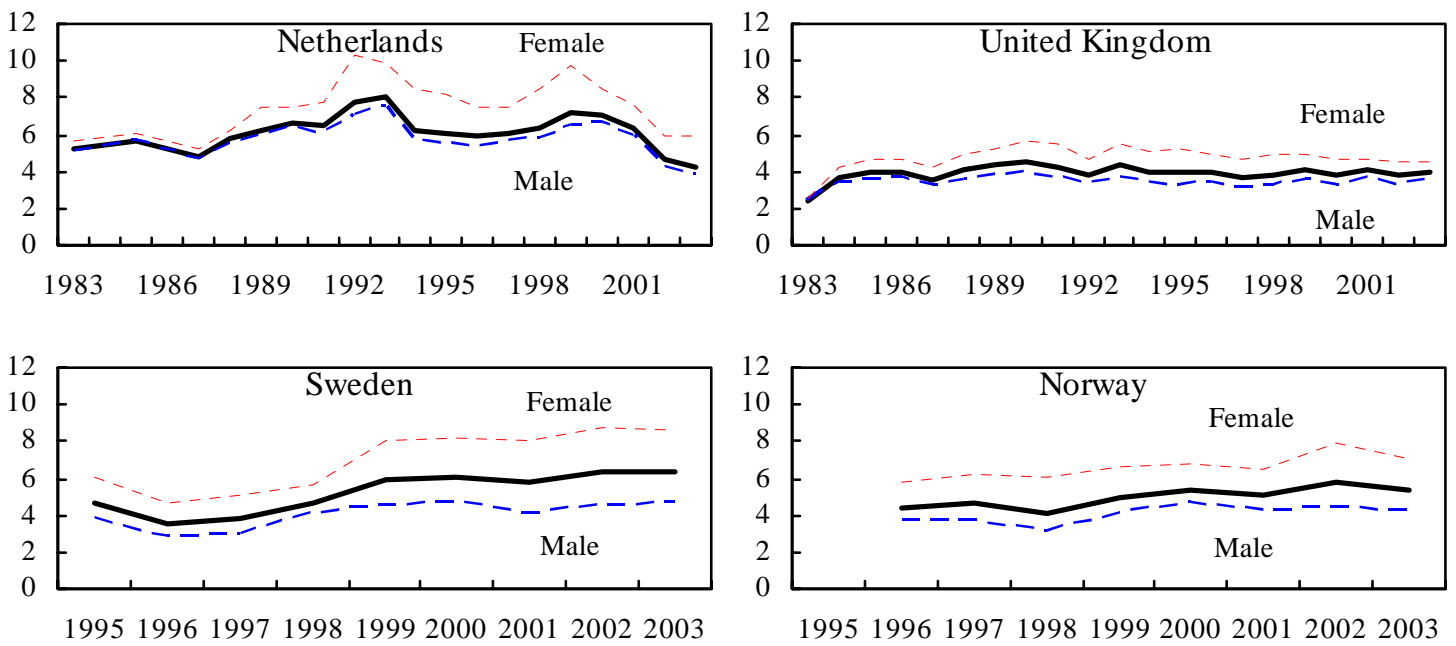

199519961997199819992000200120022003

199519961997199819992000200120022003
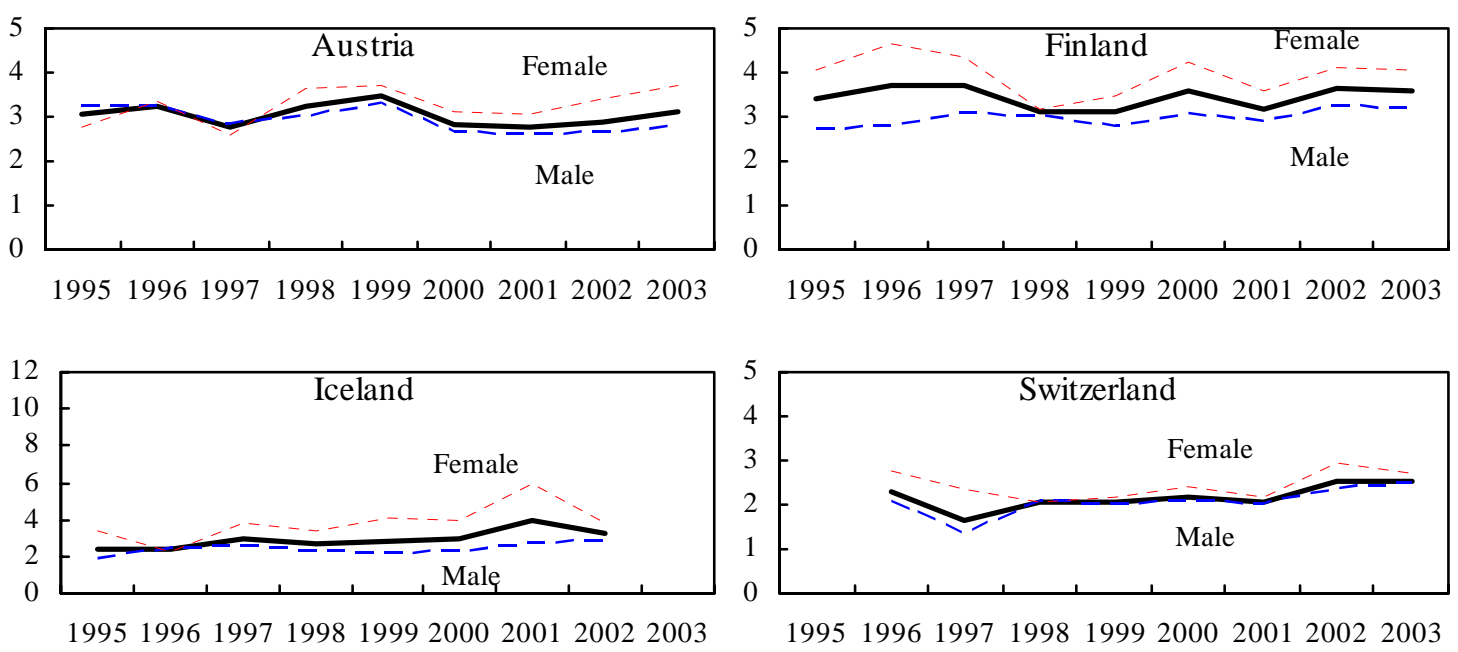

199519961997199819992000200120022003

199519961997199819992000200120022003

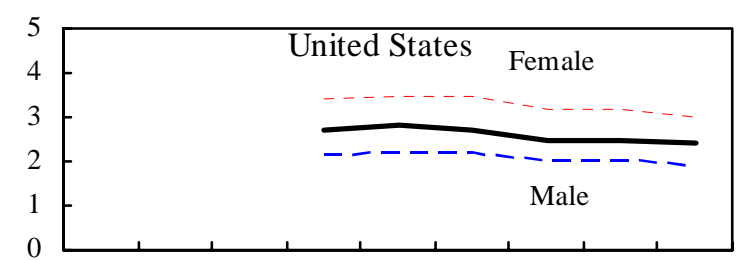

199519961997199819992000200120022003

Sources: Eurostat, NewCronos; and U.S. Department of Labor, Bureau of Labor Statistics. 
Absence spells tend to be longer than one week in most countries (Figure 4). In the United Kingdom and Iceland, short-term absence is more frequent. In The long-term Figure 4. Short- and Long-Term Sickness Absence (as a percentage of employment, average for 1995-2003) component fully explains the recent increase in absence in Sweden and Belgium (Figure 5). The increase in long-term sickness is of particular concern because longer absence is likely to be associated with a shift to disability pension. Palme and Svensson (2003) show that this has become one of the most common ways to exit the labor force before the statutory retirement age in Sweden. In Belgium, the increase most likely reflects the extension of various sabbatical leave schemes introduced in 1998.

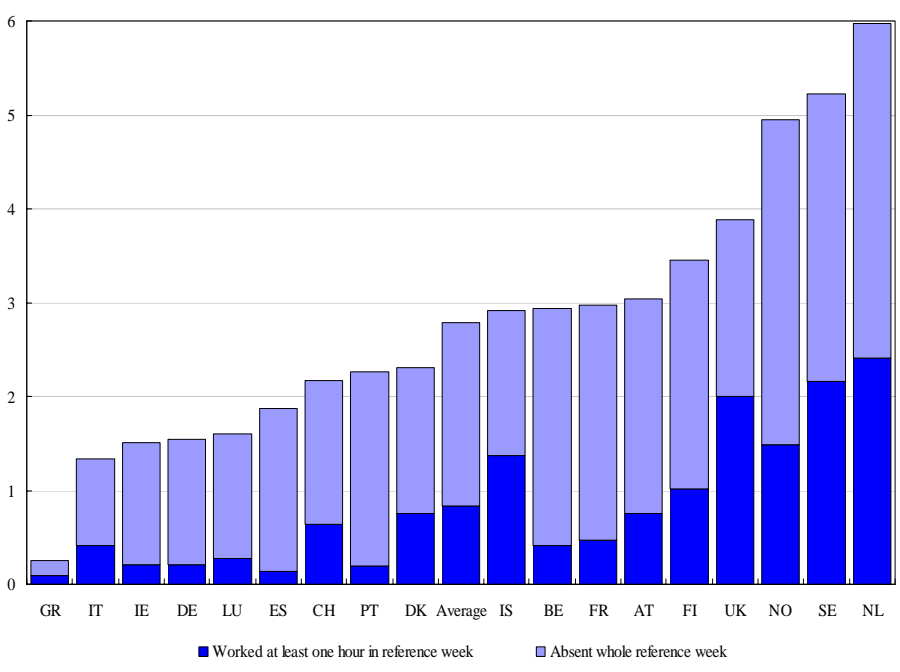

Source: Eurostat, NewCronos.

Notes: $\mathrm{AT}=$ Austria; $\mathrm{BE}=$ Belgium; $\mathrm{CH}=$ Switzerland; $\mathrm{DE}=$ Germany; $\mathrm{DK}=$ Denmark; $\mathrm{ES}=$ Spain; FI=Finland; FR=France; GR=Greece; IE=Ireland; IS=Iceland; IT=Italy; LU=Luxembourg; NL= Netherlands; NO=Norway; PT=Portugal; SE=Sweden; UK=United Kingdom

Figure 5. Belgium and Sweden: Short- and Long-Term Sickness Absence (as a percentage of employment)
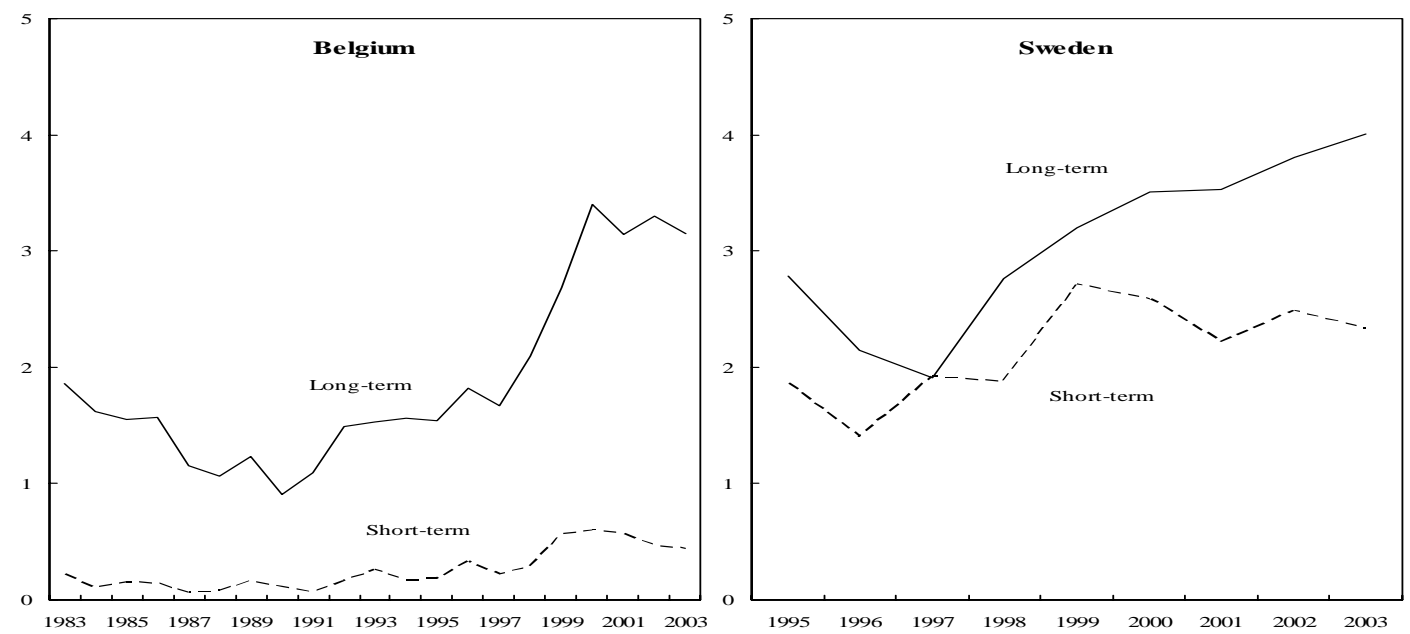

Source: Eurostat, NewCronos. 
In most countries, public sector employees are more likely to be on sick leave than those in the private sector (Table 1). To some extent, this reflects the large proportion of women in public employment. The difference in sickness absence between public and private sector is wider in countries characterized by high overall absence. For Nordic countries, where the share of public sector employment is particularly large, this composition effect can be quite important.
Table 1. Sickness Absence in Public and Private Sectors (average for 1996-2000)

\begin{tabular}{|c|c|c|c|}
\hline & \multicolumn{2}{|c|}{ Sickness absence rate $1 /$} & \multirow{2}{*}{$\begin{array}{c}\text { Share of public } \\
\text { sector } \\
\text { employment }\end{array}$} \\
\hline & $\begin{array}{l}\text { Public } \\
\text { sector }\end{array}$ & $\begin{array}{c}\text { Private } \\
\text { sector }\end{array}$ & \\
\hline France & 2.4 & 2.4 & 36.8 \\
\hline Germany & 1.4 & 1.4 & 29.8 \\
\hline Denmark & 1.7 & 1.5 & 38.9 \\
\hline Finland & 2.4 & 2.2 & 35.5 \\
\hline Netherlands & 4.7 & 3.8 & 34.4 \\
\hline Norway & 3.8 & 3.3 & 38.4 \\
\hline Sweden & 3.7 & 2.8 & 40.7 \\
\hline United Kingdom & 2.3 & 1.7 & 33.0 \\
\hline
\end{tabular}

Source: Bergendorff and others (2004).

$1 /$ Number of absentees for at least one week in percentage of all employees.

Sickness absence appears to be procyclical in some countries. Table 2 reports the correlation coefficients between sickness absence and the unemployment gap-defined as the percentage deviation of the unemployment rate from its trend (linear and quadratic) during 1995-2003. The correlation is negative and significant at the 5 percent level for three countries (Belgium, Sweden, and the Netherlands). Pro-cyclicality of work absence may arise due to two main reasons suggested in the literature (Leigh, 1985; Kaivanto, 1997; Audas and Goddard, 2001). High unemployment acts a "disciplining device" (Shapiro and Stiglitz, 1984), raising the expected cost of absence to workers. Others emphasize a "selection" effect, as employers are more likely to lay off absence-prone workers in recessions, and hire them during expansions. Arai and Skogman Thoursie (2001) provide evidence in favor of the market discipline effect in Sweden. However, the strength of proTable 2. Cyclicality of Sickness Absence, 1995-2003 (correlation between sickness absence and unemployment gap)

\begin{tabular}{lcc}
\hline & Linear trend & Quadratic trend \\
\hline Belgium & $-0.88^{*}$ & $-0.82^{*}$ \\
Denmark & 0.09 & 0.08 \\
Germany & -0.24 & -0.23 \\
Greece & -0.03 & -0.36 \\
Spain & 0.21 & 0.30 \\
France & -0.26 & 0.03 \\
Ireland & 0.13 & 0.04 \\
Italy & 0.25 & 0.30 \\
Luxembourg & 0.27 & 0.28 \\
Netherlands & -0.14 & $-0.47^{*}$ \\
Austria & 0.16 & 0.28 \\
Portugal & 0.23 & 0.43 \\
Finland & 0.03 & 0.06 \\
Sweden & $-0.52^{*}$ & $-0.51^{*}$ \\
United Kingdom & 0.06 & -0.03 \\
Iceland & -0.31 & -0.24 \\
Norway & -0.07 & 0.17 \\
Switzerland & -0.16 & -0.09 \\
\hline
\end{tabular}

Sources: Eurostat, Labour Force Survey; OECD, Economic Outlook; and Fund staff calculations.

Note: ${ }^{*}=$ significant at $5 \%$ significance level. cyclicality in countries where employment protection is high may cast some doubt on this interpretation. An alternative explanation could rely on sick leave as a reaction to work pressures, which are likely to be more intense when production volumes are high and labor flexibility is limited. 
Work absence has substantial costs for public finances, employers, and workers. Public sickness benefits reach $1 \frac{1}{2}$ percent of GDP in the Netherlands (Table 3). For Sweden, the amount of general government's transfers related to illness, including disability pensions, reaches almost 5 percent of GDP. At the same time, total costs of worker's ill health to employers can be estimated to be around 4 percent of GDP in Sweden, of which $1 / 7$ is paid directly to employees in cash benefits while the rest are contributions to the public insurance system and collectivelyagreed sickness insurance schemes. Workers generally pay a contribution to the public insurance system through their tax bill.

A first glance at the evidence suggests that labor supply characteristics, insurance provisions, and labor market institutions are important. Higher labor force participation and, particularly, higher female participation is normally associated with higher sickness absence (Figure 6). The relationship with age and health indicators, however, is less clear. Figure 6 presents the index of generosity of the sickness insurance system, both alone and combined with the unemployment insurance system, based on Scruggs (2004). The figures indeed show that absence increases with the generosity of sickness insurance and even more so when the unemployment insurance system is considered. Moreover, there is evidence that temporary workers, who enjoy lower employment protection, tend to be less sickness prone than permanent workers (Table 4).
Table 3. Public Sickness Benefits (as a percentage of GDP)

\begin{tabular}{lcc}
\hline & $1980-89$ & $1990-99$ \\
\hline Netherlands & 2.18 & 1.55 \\
Sweden & 2.19 & 1.39 \\
Norway & 1.53 & 1.35 \\
Spain & 0.82 & 1.11 \\
Ireland & 1.68 & 0.90 \\
Greece & 0.16 & 0.79 \\
Luxembourg & 0.75 & 0.74 \\
Denmark & 1.38 & 0.66 \\
Finland & 0.53 & 0.55 \\
Portugal & 0.53 & 0.55 \\
France & 0.57 & 0.54 \\
Switzerland & 0.26 & 0.52 \\
Italy & 0.32 & 0.47 \\
Belgium & 0.66 & 0.44 \\
Germany & 0.36 & 0.41 \\
United States & 0.25 & 0.24 \\
Austria & 0.22 & 0.21 \\
United Kingdom & 0.15 & 0.19 \\
Iceland & n.a. & 0.09 \\
\hline
\end{tabular}

Source: OECD, Social Expenditures Database.

Table 4. Ratio of Sickness Absence of Permanent Workers to Temporary Workers

\begin{tabular}{lcc}
\hline & 1995 & 2000 \\
\hline France & 2.4 & 2.4 \\
Germany & 1.4 & 1.4 \\
Denmark & 1.7 & 1.5 \\
Finland & 2.4 & 2.2 \\
Netherlands & 4.7 & 3.8 \\
Norway & 3.8 & 3.3 \\
Sweden & 3.7 & 2.8 \\
United Kingdom & 2.3 & 1.7 \\
\hline
\end{tabular}

Source: Bergendorff and others (2004). 
Figure 6. Sickness Absence and Its Determinants (absentees as a percentage of employment)

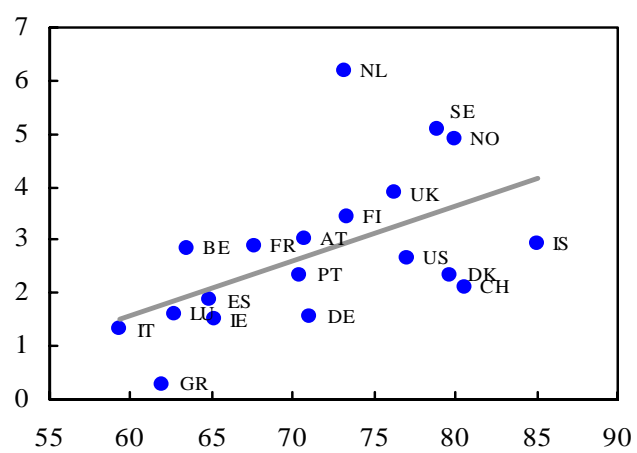

Labor force participation rate - age group 15-64, \%, 1995-2002

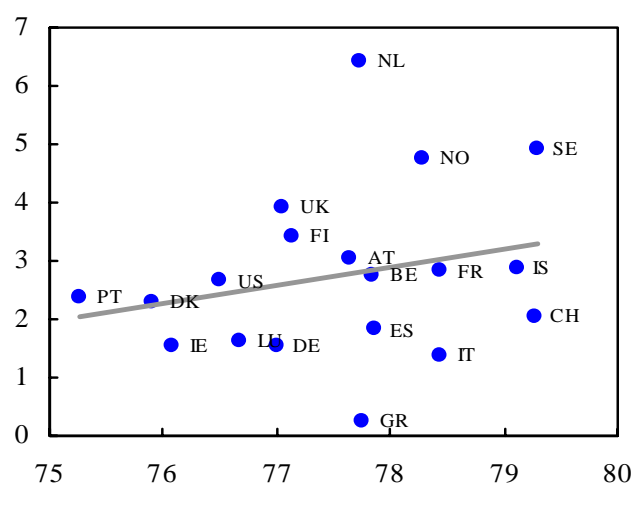

Life expectancy at birth, 1995-2001

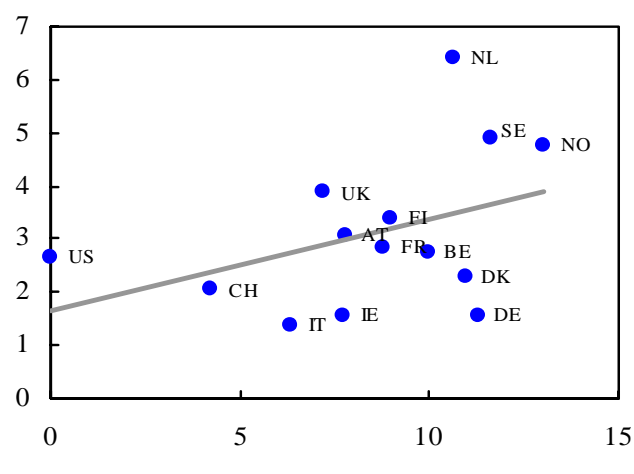

Index of sickness insurance system generosity, 1995-2001

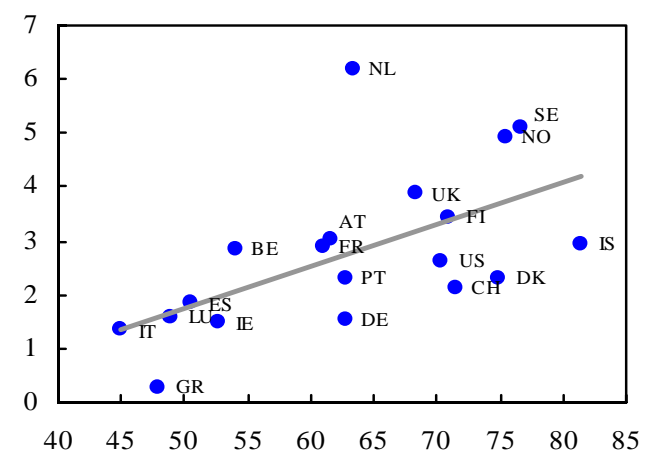

Female labor force participation rate - age group 15-64, $\%, 1995-2002$

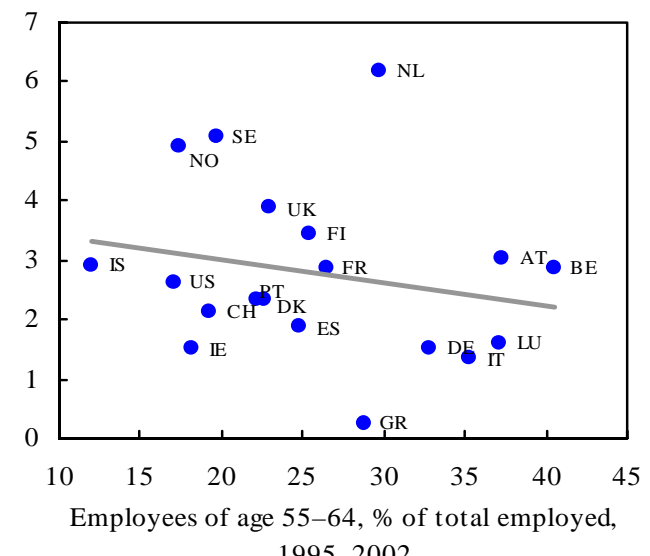

1995-2002

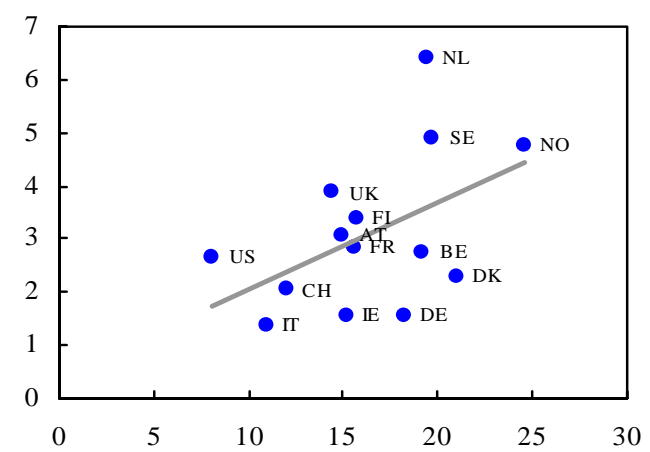

Index of sickness and unemployment insurance systems generosity, 1995-2001

Sources: Eurostat, NewCronos; International Labour Organization, Key Indicators of the Labour Market; OECD, Health Data; and Scruggs (2004).

Notes: AT= Austria; $\mathrm{BE}=$ Belgium; $\mathrm{CH}=$ Switzerland; $\mathrm{DE}=$ Germany; $\mathrm{DK}=$ Denmark; ES=Spain; FI=Finland; FR=France; $\mathrm{GR}=$ Greece; IE=Ireland; IS=Iceland; IT=Italy; LU=Luxembourg; NL= Netherlands; NO=Norway; PT=Portugal; $\mathrm{SE}=$ Sweden; UK=United Kingdom; US=United States. 
The sickness insurance systems are most generous in the Nordic countries and Germany (see Appendix II). Cash benefit replacements rates are high—as high as 100 percent in Norway - with many labor contracts providing for an additional benefit from employers. Coverage tends to be universal and benefits are provided for a long period. Sickness benefit can be generally converted into a disability pension if the illness continues for a long time. In the last twenty years, most countries have cut replacement rates. In Finland, for example, the after-tax replacement rate fell by more than 11 percentage points when comparing the last two decades (Figure 7, left panel). However, the overall generosity of the system-including also other aspects like coverage, duration, qualifying and waiting period-has actually increased in some cases (Figure 7, right panel). In the United Kingdom, for example, the entitlement period has been substantially extended.

Figure 7. Changes in Sickness Insurance System, 1983-2002

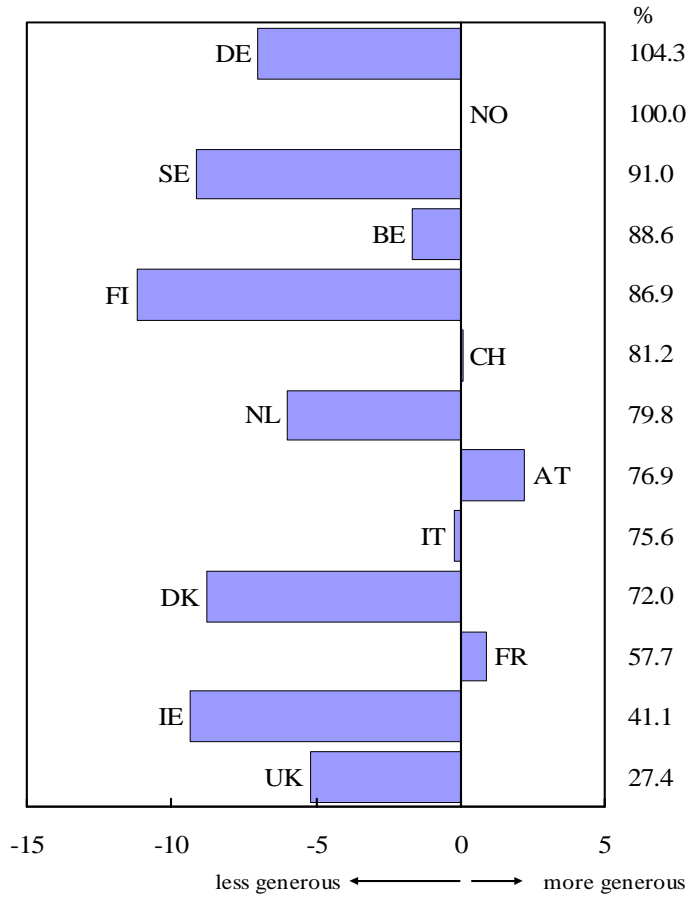

Change in average sickness benefit net replacement rate between 1993-2002 and 1983-1992, percentage points

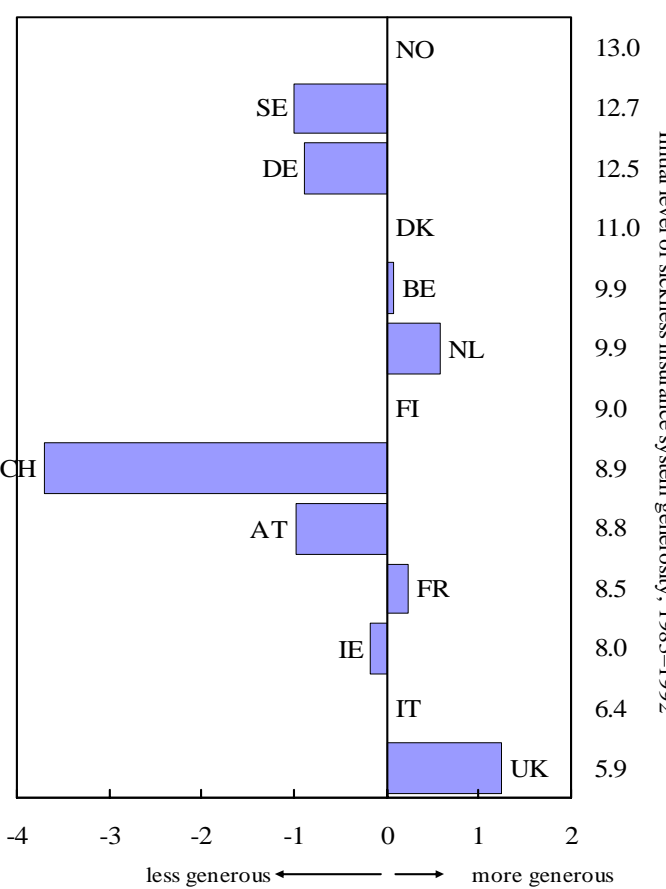

Change in sickness insurance system generosity between 1993-2002 and 1983-1992 
The incentives stemming from the insurance scheme may have a strong impact on absence behavior. There is a large Swedish literature providing empirical evidence of strong moral hazard effects of the insurance scheme. ${ }^{4}$ Skogman Thoursie (2002), for example, finds a noticeable increase in male sick absence when popular sport events take place. The interaction of sickness insurance with other elements of the social insurance system may also produce perverse incentives. Larsson $(2002,2004)$ finds that higher compensation in Sweden motivates middle- and high-wage unemployed to report sick, increasing sickness claims by as much as one third in that income group. Harmonization of the replacement rates and income ceilings between sickness and unemployment insurance systems in 2003 largely eliminated this incentive. ${ }^{5}$ She also finds that unemployed increase sick reporting to preserve their benefit status as the end of the entitlement period for unemployment benefits (60 weeks) approaches. Palme and Svensson (2003) identify a link between sickness insurance, disability pensions, and early retirement in Sweden.

Employers' responsibility in sharing the costs of the public insurance scheme can create a stronger incentive for employers to reduce sickness absence. Provisions vary widely across countries. Figure 8 shows a measure of costs to employers of the public insurance system, which reflects the gross replacement rate of benefits paid and their average duration. ${ }^{6}$ Employers' costs are highest in Austria and the Netherlands. The Netherlands has taken a radical approach in 1996, making employers responsible for the full cash benefit payment up to one year of absence. Most firms, however, opted to reinsure their sick pay liability with private insurance companies, reducing the incentive effect. Nonetheless, De Jong and Lindeboom (2004) do not find any difference in absence rates of firms that opted for reinsurance. Although any conclusion from that experience is still tentative, absence started declining three years later and has now dropped below the Swedish level.

\footnotetext{
${ }^{4}$ See, for example, Henrekson and Persson (2004); Andrén (2001a, 2001b, 2003); Johansson, and Palme (1996, 2002); and Skogman Thoursie (2002).

${ }^{5}$ However, some residual incentives to shift to the sickness insurance remain for some categories of unemployed, such as the long-term unemployed, those who have seen their benefit reduced for having refused a job offer, and those who enjoy additional sickness benefits as part of their contracts. We owe this observation to Laura Larsson.

${ }^{6}$ This measure does not include the costs to employers deriving from separate provisions negotiated with workers.
} 
Figure 8. Sickness Cash Benefits Paid by Employer

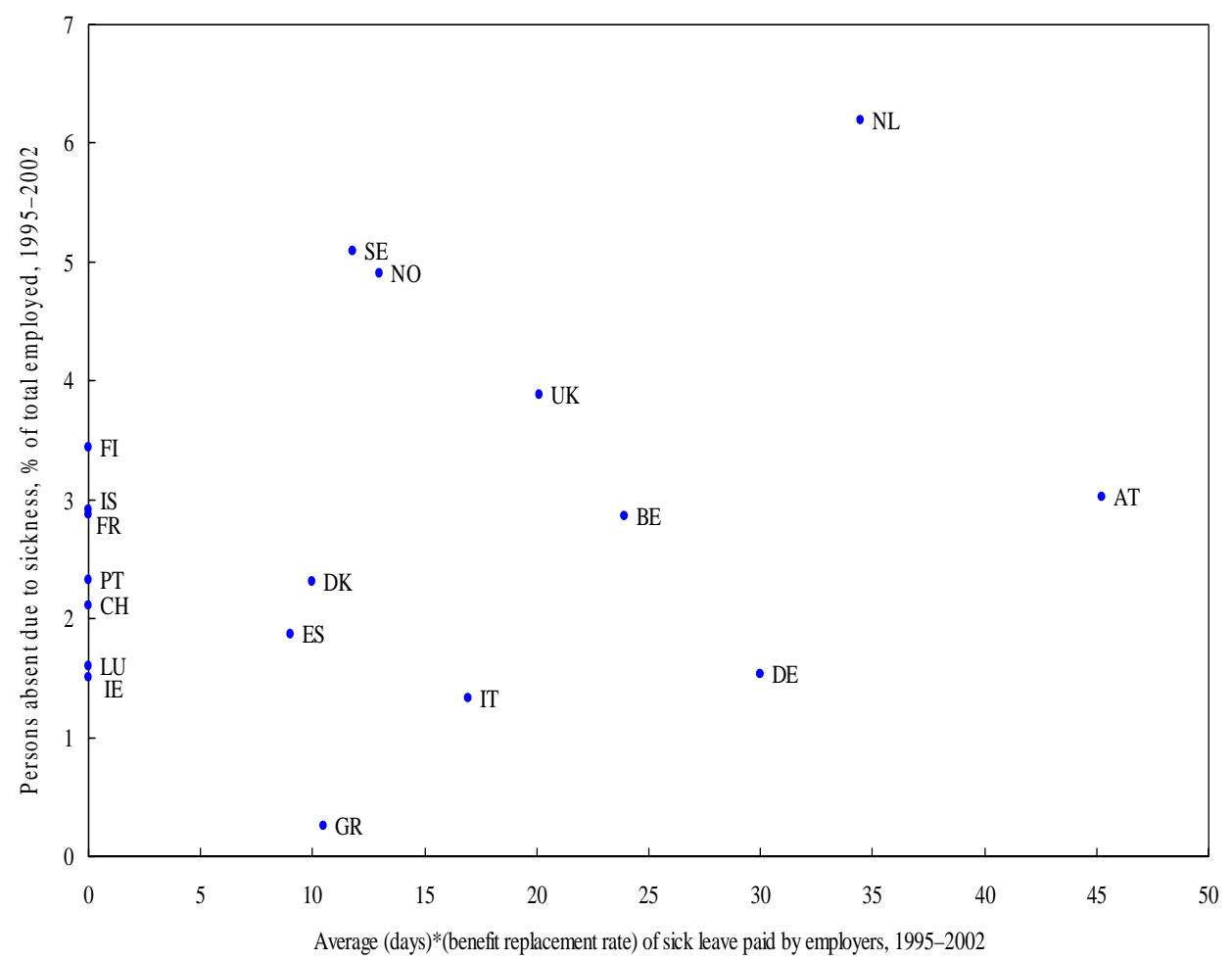

Sources: U.S. SSA, Social Security Programs Throughout the World; Eurostat, NewCronos; and Fund staff calculations. Notes: AT= Austria; $\mathrm{BE}=$ Belgium; $\mathrm{CH}=$ Switzerland; $\mathrm{DE}=$ Germany; DK=Denmark; $\mathrm{ES}=$ Spain; FI=Finland; FR=France; $\mathrm{GR}=$ =Greece; IE=Ireland; IS=Iceland; IT=Italy; LU=Luxembourg; NL= Netherlands; NO=Norway; PT=Portugal; SE=Sweden; UK=United Kingdom.

Long working hours may increase absence, while flexible working arrangements should reduce it. Usual hours of work, as measured by labor force surveys, show a wide range, with Iceland and the United Kingdom at the top (Figure 9, left panel). The United Kingdom, in particular, presents a large difference between usual hours worked (43.2 hours per week in 2003) and the average working time collectively agreed between employers and unions (37.2 hours per week). Figure 9, right panel indicates that the diffusion of part-time arrangements varies widely between the Netherlands (more than 30 percent of employment) and Greece (about 7 percent).

In sum, a first glance at the data on sickness absence and on a broad range of variables that may affect absence behavior suggests a presence of large differences across Europe, both in terms of the importance of the problem and of the evolution of the sickness absence and its determinants. Sickness absence rates-being relatively stable over time, higher for women, 
Figure 9. Working Time Arrangements
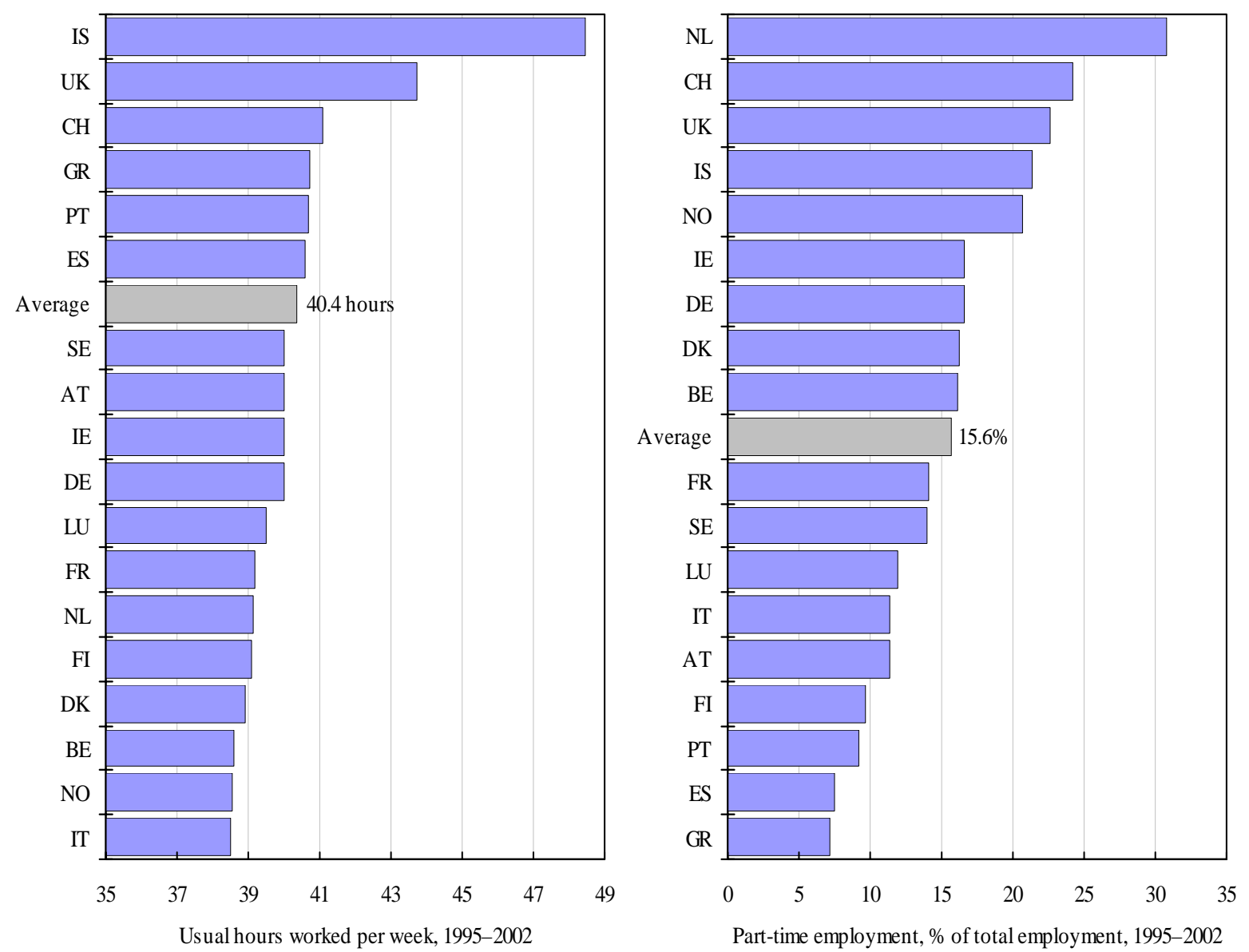

Sources: Eurostat, NewCronos; and International Labor Organization, Key Indicators of the Labour Markets.

Notes: $\mathrm{AT}=$ Austria; $\mathrm{BE}=$ Belgium; $\mathrm{CH}=$ Switzerland; $\mathrm{DE}=$ Germany; $\mathrm{DK}=$ Denmark; $\mathrm{ES}=$ Spain; FI=Finland; FR=France; GR=Greece; IE=Ireland; IS=Iceland; IT=Italy; LU=Luxembourg; NL= Netherlands; NO=Norway; PT=Portugal; SE=Sweden; UK=United Kingdom.

and mainly lasting longer than a week-appear to be pro-cyclical and higher among the employees who generally enjoy stronger employment protection. High labor force participation and more generous sickness insurance systems tend to be positively associated with higher sickness absence rates. At the same time, a more rigorous investigation of the determinants of sickness absence is needed, taking into account also some demographic characteristics, working time arrangements and employers' incentives. Hence, while the next section helps us to structure the discussion within a stylized model of work absence, the following section continues the empirical analysis using a multivariate approach. 


\section{THE MODEL}

This section presents an analysis of work absence within a simple stylized model of both labor supply and labor demand. ${ }^{7}$ On the supply side, the conventional determinants of the labor-leisure choice are augmented to include a number of institutional characteristics. In particular, the generosity of paid leave provisions is included. The penalty for being absent is modeled as (the inverse of) the probability of keeping the job. The latter is assumed to depend upon the absence behavior with its impact on the probability being dependent upon the strictness of employment protection.

The economy is populated by a large number of workers whose mass is normalized to one. The worker's preference towards absence is given by the desired absence hours, $a$, such that $a \in[0, c]$, where, if contracted hours of work are given by $c$ and total number of hours is normalized to $1, a=0$ indicates no absence, and $a=c$ corresponds to full absence from work. ${ }^{8}$ On the labor demand side, a profit-maximizing firm chooses its desired input of hours of work, which in case of a given number of contracted hours, translates into a decision on the absence tolerance. As a result of the maximization problems of the worker and the firm, an equilibrium pair of absence rate and wage is determined.

\section{A. Labor Supply (Hours Decision)}

Let a worker's maximization problem be given by

$\max U(x, l)$

subject to

$x=R+P(A, V) w(c-\beta a)+[1-P(A, V)][B+G(\gamma)]$

$l=1-(c-a)$

where $x$ and $l$ are consumption and leisure, respectively, $R$ is non-labor income, $w$ is wage, $c$ is the given contractual hours of work, $a$ is absence hours (due to sickness), $\beta$ is the inverse of the sickness benefit replacement rate (ratio of sick pay to wage) such that $\beta \in[0,1]$ with $\beta=0$ corresponding to the case when sickness absence is fully compensated (100 percent replacement rate) and $\beta=1$ when there is no compensation. $B$ is unemployment benefits. $\gamma$ is the degree of employment protection and/or level of

\footnotetext{
${ }^{7}$ Brown and Sessions (1996) provide an extensive survey of the theoretical literature on labor absence.

${ }^{8} \mathrm{We}$ focus only on work absence, while a more general setup could consider also overtime work, such that $a \in[-(1-c), c]$, where $a=-(1-c)$ would be the extreme case of overtime work for the part of the total time remaining after the contracted hours of work.
} 
unionization, and can in general be regarded as a combination of all those labor market regulations that impose costs for employers to discipline/dismiss employees. Assume $\gamma \in[0,1]$ where $\gamma=1$ is the situation of 'complete' employment protection (no firing possibility) and $\gamma=0$ is the case of no protection at all. $G$ is the firing-related entitlements, such that higher entitlements are associated with stronger employment protection, $G_{\gamma}(\gamma)>0$, and $G(0)=0$. The probability of keeping the job, $P(A, V)$, is a function of the joint impact of absence behavior, $a$, and employment protection, $\gamma$, denoted by $A$, such that the probability of keeping the job declines with absence, $P_{a}()<$.0 , and increases with the degree of employment protection, $P_{\gamma}(\cdot)>0 . P(A, V)$ is also assumed to depend on a joint impact of some business cycle characteristics, $v$, and employment protection, $\gamma$, denoted by $V$, such that, if $v$ is a procyclical variable, the probability of remaining employed is higher during upswings $P_{v}(\cdot)>0$. Also assume $P_{a v}(\cdot)=0$. Finally, the following standard assumptions about the utility function are made: $U_{x}(\cdot)>0, U_{l}(\cdot)>0, U_{x x}(\cdot)<0, U_{l l}(\cdot)<0, U_{x l}(\cdot)=0$.

Thus, the budget constraint (2) states that income spent on consumption is equal to the sum of non-labor income and wage income if the worker retains her job or unemployment and other firing entitlements if the worker is dismissed. ${ }^{9}$ In turn, the time constraint (3) assumes that if total hours are normalized to 1, then leisure time is the difference between total and actual hours worked.

\section{B. Labor Demand}

The firm maximizes its profit given by

$$
\Pi=Y-P(A, V) w(c-\theta \beta a)-[1-P(A, V)] G(\gamma)
$$

where

$$
Y=A k^{1-\eta}(c-a)^{\eta}
$$

is the production function, which depends on actual hours worked, $(c-a)$, with the labor share being $\eta$. Note that the replacement rate $\beta$ enters the profit equation (4) with an additional parameter $\theta$, which indicates whether the insurance system is private or public, i.e. whether sick pay is paid by the firm or by the government. In particular, if the employer pays sick pay at the rate $\beta$, as set by regulations, then $\theta=1$. Alternatively, $\theta=1 / \beta$. We will discuss these two cases separately when deriving the main results below.

\footnotetext{
${ }^{9}$ Equation (2) can be considered as the present value of expected future income, where the infinite summation and discounting have been ignored for simplicity.
} 


\section{Solution}

From the first-order conditions of the optimization problems (1)-(3) and (4)-(5) with respect to the absence hours, $a$, we can obtain the optimal wage for the worker and the firm from equations (6) and (7) below, respectively

$$
\begin{gathered}
w^{W}=\frac{P_{a}(B+G)-\frac{U_{l}}{U_{x}}}{P_{a}(c-\beta a)-P \beta} \\
w^{F}=\frac{Y_{a}+P_{a} G}{P_{a}(c-\theta \beta a)-P \theta \beta}
\end{gathered}
$$

\section{Case 1: Privately financed insurance}

As discussed above, when sickness benefits are paid by the firm, $\theta=1$, and hence equating (6) and (7) yields

$$
\frac{U_{l}}{U_{x}}-P_{a} B=-Y_{a}
$$

stating that in equilibrium, the marginal product of labor $\left(-Y_{a}\right)$ equals the marginal rate of substitution (MRS) between leisure and consumption net of the marginal unemployment benefit. Recall that $P_{a}<0$ hence MPL should be higher or, alternatively, MRS should be lower than in the case when $P_{a} B=0$. Graphically, in the latter case the indifference curve shifts down along the production function frontier resulting in an increasing absence time (Figure 10).

Using the Implicit Function Theorem it can be shown that equilibrium hours of absence, $a^{*}$, decline with the inverse of the replacement rate (equivalently, increase with generosity of sickness benefits) and increase with the degree of employment protection and contractual hours. Higher absence is also positively related to cyclical expansions, unemployment benefits, and non-labor income. ${ }^{10}$ The equilibrium wage is then obtained by evaluating (6) or (7) at the point $a=a^{*}$.

$$
a^{*}=a\left(\begin{array}{c}
\beta, \gamma, c, v, B, R \\
-++++++
\end{array}\right)
$$

${ }^{10}$ Relation (9) can be obtained by assuming additionally that $w(c-\beta a)-(B+G)>0$ and $P_{a a}(\cdot) \geq 0$. 
Figure 10. Model Equilibrium

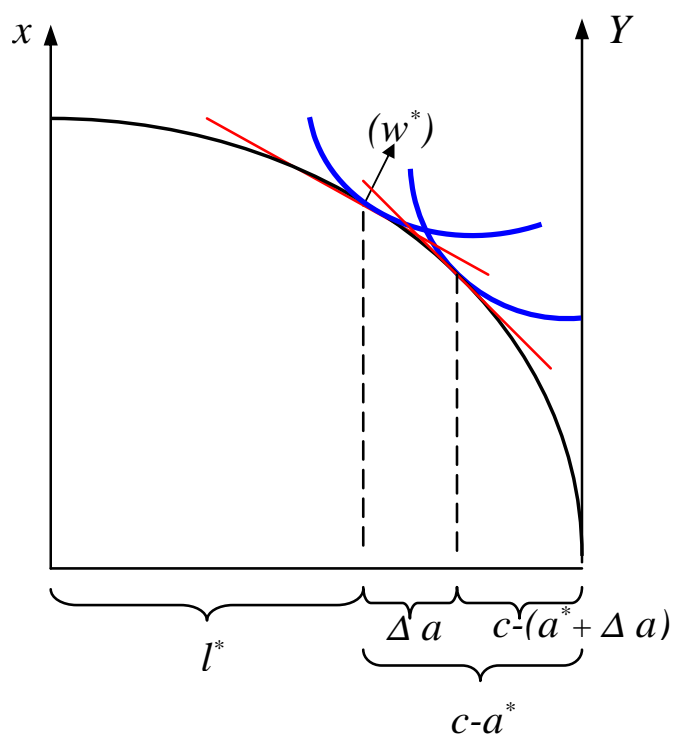

Assuming $U(x, l)=(1-\sigma) \ln x+\sigma \ln l$, where $\sigma \in[0,1]$ can be interpreted as the value of leisure or sickness index, note that in the special case when $B=0$ the solution (9) simplifies to

$$
a^{*}=c-\frac{1}{1+\frac{x}{Y} \frac{\sigma}{\eta(1-\sigma)}}
$$

which, similar to Prescott (2004), suggests that (i) as $\sigma$ goes to 1 and the worker values leisure more than consumption because of, say, recuperation time, the optimal absence time approaches contractual hours; (ii) the smaller is the labor share in the production function the higher is the absence time; and (iii) as the consumption-output ratio increases the absence time also increases.

\section{Case 2: Publicly financed insurance}

Similarly, when the employer does not pay for the sickness absence, and $\theta=1 / \beta$, from (6) and (7) we have

$$
\frac{P_{a}(B+G)-\frac{U_{l}}{U_{x}}}{P_{a}(c-\beta a)-P \beta}=\frac{Y_{a}+P_{a} G}{P_{a}(c-a)-P}
$$


which after some algebraic transformations yields

$$
Q+\frac{N(1-\beta)\left(Y_{a}+P_{a} G\right)}{(M-N)}=0
$$

where $Q=Y_{a}+\frac{U_{l}}{U_{x}}-P_{a} B, M=P_{a} c$, and $N=P_{a} a+P$. Note that eq. (12) differs from the above case when $\theta=1$ (eq. 8 ) by the second term, that is, the difference between equilibrium absence under public and private insurance is given by $D=\frac{N(1-\beta)\left(Y_{a}+P_{a} G\right)}{M-N}$, which will be equal to zero if $\beta=1$ (no compensation for absence) and/or $N=0 .{ }^{11}$ Note also that $D$ has the same sign as $N$ and that given our assumptions on the function $P, N_{a}<0$. Thus, similar to eq. (8), eq. (12) can be re-written as

$$
\frac{U_{l}}{U_{x}}-P_{a} B+D=-Y_{a}
$$

from which it follows that when $N>0(N<0)$ the absence in the case of the publicly financed system is higher (lower) than in the case of the employer paying all benefits $(D=0)$. Observe that the condition $N>0(N<0)$ can be re-written as $\varepsilon_{P a}>-1\left(\varepsilon_{P a}<-1\right)$ where $\varepsilon_{P a} \in(-\infty, 0]$ is the elasticity of the probability of keeping the job, $P$, with respect to absence, $a$. This implies that privately financed system will yield lower absence than the publicly financed one if the elasticity of the probability of being fired with respect to absence is low. In other words, if the decision on the employment continuation is not very sensitive to the absence behavior, then to achieve a lower absence it is optimal to shift to employers the responsibility for sickness insurance costs.

\section{ECONOMETRIC ANALYSIS}

\section{A. Data}

While the empirical literature on work absence in individual countries is vast, only a few cross-country comparative studies exist (Drago and Wooden, 1992; Barmby and others,

\footnotetext{
${ }^{11}$ The latter condition requires some strict assumptions on the probability function to be inversely dependent on $a$ (only or separably from $v$ ), and, given that $P$ is a probability and $a<1$, on the constant term in the solution of the differential equation.
} 
2002; Bergendorff and others, 2004). In this paper, we try to identify the determinants of sickness absence in a panel of 18 European countries (Table A.1 in Appendix I).

The data on sickness absence draw on labor force surveys, and particularly, on the Eurostat Labour Force Survey Results, which includes aggregated data on average usual and actual hours of work. Our definition of absence includes both short-term and long-term absentees. ${ }^{12}$ Data on age, health, unemployment, and participation are drawn from the ILO's Key Indicators of the Labour Market (KILM). Data on institutional characteristics of social security systems are derived from Scruggs (2004). Data on the cost to employers of the sickness insurance system have been constructed based on information from the U.S. Social Security Administration, Social Security Programs Throughout the World (Table A.2 in Appendix I). Basic descriptive statistics of the variables used in the analysis and their crosscorrelations are summarized in Tables A.3 and A.4 in Appendix I, respectively.

\section{B. Empirical Strategy}

The econometric exercise is based on standard panel data models. While lacking extensive cross-sectional information typical of microeconomic datasets, this approach allows us to analyze sickness absence developments over time and across countries. The availability of working time data and some of the absence determinants by gender makes it possible to combine sickness absence for males and females and to double the effective cross-sectional dimension of the panel data.

In a general setup, the model is given by

$a_{i, t}=\sum_{j=1}^{k} a_{i, t-j} \beta_{0, j}+X_{i, t} \beta_{1}+W_{i, t} \beta_{2}+\eta_{i}+\varepsilon_{i, t}, \quad i=1, \ldots N ; t=1, \ldots, T_{i} ;$

where $a_{i, t}$ is the absence rate for country-gender pair $i$ at time $t, X_{i, t}$ is a vector of exogenous covariates and $W_{i, t}$ is a vector of predetermined and endogenous covariates treated similarly to the lagged dependent variables. $X$ and $W$ may contain lagged independent variables and time dummies, and can be either gender-country or only country specific. $\eta_{i}$ is an unobserved unit-specific fixed effect, and $\varepsilon_{i, t}$ is the disturbance term.

\footnotetext{
${ }^{12}$ Employees are grouped into two main subgroups: those who worked at least one hour during the reference week, and those who had a job, but did not work at all during the reference week. The reasons provided for absence-defined as a positive difference between usual and actual hours of work-are thirteen for the first group and nine for the second group. We refer to sickness absence as that due to own illness, injury, or temporary disability. Sickness absence of those in the first group is defined as 'short-term,' that of those in the second group is defined as 'long-term.'
} 
The determinants of sickness absence have been estimated by both static and dynamic panel data (DPD) models that control for fixed effects. While the former follows the common approach applied in the earlier literature, the latter allows us to build in a richer dynamics into the relationship between absence and its determinants by taking also into account potential persistence in absence rates and endogeneity of some right-hand-side variables. Furthermore, DPD models help us to address the error autocorrelation problem which makes fixed-effects estimates inefficient and biases the inference. Serial correlation, in turn, may occur mainly because of omitting variables that change gradually over time. As the inclusion of lagged dependent variable makes the least squares dummy variable (LSDV) estimator biased, an instrumental variable or a Generalized Method of Moments (GMM) estimation method can be used. Monte Carlo results of Judson and Owen (1999) suggest that in macroeconomic panel data applications the one-step GMM estimator by Arellano and Bond (1991) is a second-best choice. ${ }^{13}$ Furthermore, as showed in Blundell and Bond (1998), persistence in the dependent variable may result in weak instruments and losses in asymptotic efficiency when using the first-differenced GMM estimator. As an alternative, the so-called system GMM estimator is suggested that combines the regressions in differences used in the standard first-differenced GMM estimation with the regressions in levels.

Our empirical strategy has been the following. For each specification static (Within or LSDV and pooled OLS) and dynamic (GMM and Anderson-Hsiao, 1982) panel data models have been estimated. ${ }^{14}$ For static models, the appropriateness of random-effects specification has been tested by the Hausman test, together with a test of serial correlation in idiosyncratic error terms (Wooldridge, 2002; Drukker, 2003). In a dynamic setup, we have used one-step GMM estimator, which generally tends to be less biased in small samples than the two-step estimator and outperforms the latter in macroeconomic applications (Judson and Owen, 1999; Lusinyan, 2003). The two-step estimator was however been used for robustness checks. The one-step estimations have been implemented using first-differenced and system GMM estimators with standard errors being both robust and non-robust to general heteroscedasticity over individuals and over time. The results have also been checked by using different sets of GMM instruments. ${ }^{15}$ Finally, robustness of the results to the exclusion of some countries from the sample have been checked as well. The results from static and dynamic panel data regressions are reported in Table 5 and Table 6, respectively.

\footnotetext{
${ }^{13}$ The LSDV estimator with the Kiviet's (1995) correction outperforms all other estimators in small samples, but an implementation of this technique for unbalanced panels has not been derived.

${ }^{14}$ The dependent variable has been tested for nonstationarity using Levin and Lin (1992) and Im, Pesaran and Shin (1997) panel unit root tests. The results, not reported here, indicate that the null of nonstationarity can be rejected when a trend is included into the specification.

${ }^{15}$ In fact, although the GMM procedure of Arellano and Bond (1991) implies using all lagged values as instruments, Judson and Owen (1999) argue that a 'restricted GMM,' where the number of values of the lagged dependent variables and exogenous regressors used as instruments is reduced, does not substantially affect the performance of this technique.
} 
Table 5. Determinants of Sickness Absence: Static Panel Data Model (Dependent variable: share of persons absent due to sickness in total employed)

\begin{tabular}{|c|c|c|c|c|c|c|c|c|c|}
\hline & $(1)$ & $(2)^{\frac{5}{5}}$ & (3) & (4) & $(5)$ & (6) & $(7)$ & $(8)$ & $(9)$ \\
\hline$L F P R_{i, t}$ & $\begin{array}{l}0.06^{* *} \\
(5.33)\end{array}$ & $\begin{array}{l}0.06^{* *} \\
(10.59)\end{array}$ & $\begin{array}{l}0.06^{* *} \\
(5.20)\end{array}$ & $\begin{array}{l}0.06^{* *} \\
(4.29)\end{array}$ & $\begin{array}{l}0.04^{* *} \\
(3.02)\end{array}$ & $\begin{array}{l}0.06^{* *} \\
(5.06)\end{array}$ & $\begin{array}{l}0.09^{* *} \\
(4.83)\end{array}$ & $\begin{array}{l}0.08^{* *} \\
(5.32)\end{array}$ & $\begin{array}{l}0.08^{* *} \\
(5.46)\end{array}$ \\
\hline Age structure $_{i, t}$ & $\begin{array}{l}0.001 \\
(0.05)\end{array}$ & $\begin{array}{r}-0.001 \\
(0.06)\end{array}$ & & & & & & & \\
\hline Life expectancy $y_{i, t}$ & $\begin{array}{l}-0.20^{*} \\
(2.02)\end{array}$ & $\begin{array}{l}-0.21^{*} \\
(1.97)\end{array}$ & & & $\begin{array}{l}-0.16 \\
(1.30)\end{array}$ & & $\begin{array}{l}-0.41^{* *} \\
(3.19)\end{array}$ & $\begin{array}{l}-0.34^{* *} \\
(3.15)\end{array}$ & $\begin{array}{l}-0.46^{* * *} \\
(4.28)\end{array}$ \\
\hline Part-time empl $l_{i, t}$ & & & $\begin{array}{l}-0.29^{*} \\
(2.24)\end{array}$ & $\begin{array}{l}-0.28^{-} \\
(1.60)\end{array}$ & & & $\begin{array}{l}-0.67^{* * *} \\
(3.23)\end{array}$ & $\begin{array}{l}-0.40^{*} \\
(2.20)\end{array}$ & $\begin{array}{l}-0.49^{* * *} \\
(2.65)\end{array}$ \\
\hline Usual hours $_{i, t}$ & & & & & $\begin{array}{l}0.25^{* *} \\
(2.59)\end{array}$ & $\begin{array}{l}0.29^{* *} \\
(3.89)\end{array}$ & & & \\
\hline $\begin{array}{l}\text { Part-time empl* } \\
\text { Usual hours } \\
i, t\end{array}$ & & & $\begin{array}{l}0.80^{*} \\
(2.42)\end{array}$ & $\begin{array}{l}0.85^{+} \\
(1.90)\end{array}$ & & & $\begin{array}{l}1.88^{* *} \\
(3.55)\end{array}$ & $\begin{array}{l}1.18^{*} \\
(2.53)\end{array}$ & $\begin{array}{l}1.43^{* *} \\
(2.94)\end{array}$ \\
\hline$U E \operatorname{gap}_{i, t}$ & & & & $\begin{array}{r}-0.004^{+} \\
(1.80)\end{array}$ & $\begin{array}{l}-0.01^{* * *} \\
(3.30)\end{array}$ & $\begin{array}{l}-0.001 \\
(0.44)\end{array}$ & & $\begin{array}{l}-0.01^{* *} \\
(2.77)\end{array}$ & \\
\hline Sickness benefit $_{i, t}$ & & & & & $\begin{array}{l}0.06^{* *} \\
(3.50)\end{array}$ & $\begin{array}{l}0.03^{* *} \\
(2.85)\end{array}$ & $\begin{array}{l}0.03^{* *} \\
(2.64)\end{array}$ & & \\
\hline Sweden*Sick. benefit ${ }_{i, t}$ & & & & & $\begin{array}{l}0.07^{*} \\
(2.01)\end{array}$ & & & & \\
\hline UE benefit $t_{i, t}$ & & & & & & $\begin{array}{c}-0.02^{* *} \\
(3.22)\end{array}$ & & & \\
\hline Employer sick pay $_{i, t}$ & & & & & & & $\begin{array}{c}-0.01^{* *} \\
(2.81)\end{array}$ & & $\begin{array}{l}-0.03^{* *} \\
(3.15)\end{array}$ \\
\hline$E P$ index $_{i, t}$ & & & & & & & & $\begin{array}{l}-0.28 \\
(0.73)\end{array}$ & \\
\hline$E P$ index $* U E g a p_{i, t}$ & & & & & & & & $\begin{array}{l}0.01^{*} \\
(2.39)\end{array}$ & \\
\hline EP index*Empl. sick pay $_{i, t}$ & & & & & & & & & $\begin{array}{c}0.0004^{*} \\
(2.39)\end{array}$ \\
\hline Gender & & $\begin{array}{l}-1.95^{* *} \\
(12.29)\end{array}$ & & & & & & & \\
\hline Sweden & & $\begin{array}{l}3.23^{* *} \\
(9.43)\end{array}$ & & & & & & & \\
\hline Netherlands & & $\begin{array}{l}5.15^{* *} \\
(17.39)\end{array}$ & & & & & & & \\
\hline Norway & & $\begin{array}{l}2.86^{* *} \\
(11.00)\end{array}$ & & & & & & & \\
\hline United Kingdom & & $\begin{array}{l}1.80^{* *} \\
(6.11)\end{array}$ & & & & & & & \\
\hline Constant & $13.78^{+}$ & $14.62^{+}$ & -0.95 & $16.78^{*}$ & 5.87 & $-13.25^{* *}$ & $25.10^{*}$ & $22.78^{* * *}$ & $31.29^{* *}$ \\
\hline Within $\mathrm{R}^{2}$ & $\begin{array}{c}(1.78) \\
0.18\end{array}$ & $(1.78)$ & $\begin{array}{c}(1.37) \\
0.14\end{array}$ & $\begin{array}{c}(2.08) \\
0.22\end{array}$ & $\begin{array}{c}(0.64) \\
0.51\end{array}$ & $\begin{array}{c}(4.24) \\
0.22\end{array}$ & $\begin{array}{c}(2.56) \\
0.32\end{array}$ & $\begin{array}{c}(2.80) \\
0.38\end{array}$ & $\begin{array}{c}(3.81) \\
0.39\end{array}$ \\
\hline Overall $\mathrm{R}^{2}$ & 0.01 & 0.89 & 0.03 & 0.05 & 0.01 & 0.001 & 0.02 & 0.03 & 0.02 \\
\hline Obs. (groups) & $390(36)$ & 390 & $532(36)$ & $384(36)$ & $278(26)$ & $378(26)$ & $272(26)$ & $246(30)$ & $246(30)$ \\
\hline
\end{tabular}


Table 6. Determinants of Sickness Absence: Dynamic Panel Data Model (Dependent variable: share of persons absent due to sickness in total employed)

\begin{tabular}{|c|c|c|c|c|c|c|c|c|c|}
\hline & (1) & (2) & (3) & (4) & (5) & (6) & $(7)$ & (8) & (9) \\
\hline Absence rate ${ }_{i, t-1}$ & $\begin{array}{l}0.39^{* *} \\
(3.86)\end{array}$ & $\begin{array}{l}0.58^{* *} \\
(5.60)\end{array}$ & $\begin{array}{l}0.55^{* *} \\
(6.00)\end{array}$ & $\begin{array}{l}0.49^{* *} \\
(5.91)\end{array}$ & $\begin{array}{l}0.53^{* *} \\
(8.47)\end{array}$ & $\begin{array}{l}0.54^{* *} \\
(8.57)\end{array}$ & $\begin{array}{l}0.52^{* *} \\
(8.86)\end{array}$ & $\begin{array}{l}0.37^{* *} \\
(5.37)\end{array}$ & $\begin{array}{l}0.31^{* *} \\
(3.88)\end{array}$ \\
\hline$L F P R_{i, t}$ & $\begin{array}{l}-0.05 \\
(1.17)\end{array}$ & $\begin{array}{l}-0.01 \\
(0.54)\end{array}$ & $\begin{array}{l}-0.02 \\
(1.14)\end{array}$ & $\begin{array}{l}-0.04 \\
(1.29)\end{array}$ & & & & & $\begin{array}{l}-0.07^{-} \\
(1.53)\end{array}$ \\
\hline$L F P R_{i, t-1}$ & $\begin{array}{c}0.04 \\
(1.02)\end{array}$ & $\begin{array}{l}0.03 \\
(1.11)\end{array}$ & $\begin{array}{l}0.04^{+} \\
(1.70)\end{array}$ & $\begin{array}{l}0.05^{*} \\
(2.05)\end{array}$ & & & & & $\begin{array}{l}0.11^{* *} \\
(2.64)\end{array}$ \\
\hline Age structure $_{i, t}$ & $\begin{array}{c}0.03 \\
(0.64)\end{array}$ & & & & & & & & \\
\hline Life expectancy $y_{i, t}$ & $\begin{array}{l}-0.16^{*} \\
(1.97)\end{array}$ & & & & & & & & \\
\hline Flexible hours ${ }_{i, t}$ & & $\begin{array}{l}-0.29^{*} \\
(2.50)\end{array}$ & & & & & & & \\
\hline Usual hours $_{i, t}$ & & & $\begin{array}{l}0.20^{* *} \\
(2.68)\end{array}$ & & $\begin{array}{l}0.19^{*} \\
(2.37)\end{array}$ & $\begin{array}{l}0.16^{+} \\
(1.89)\end{array}$ & $\begin{array}{l}0.25^{*} \\
(2.19)\end{array}$ & $\begin{array}{l}0.21^{*} \\
(2.10)\end{array}$ & $\begin{array}{l}0.21^{* *} \\
(5.00)\end{array}$ \\
\hline $\begin{array}{l}\text { Usual hours* } \\
\quad \text { Flexible hours }{ }_{i, t}\end{array}$ & & $\begin{array}{l}0.62^{*} \\
(2.36)\end{array}$ & $\begin{array}{l}-0.09^{*} \\
(2.22)\end{array}$ & & & & & & \\
\hline Part-time empl $l_{i, t}$ & & & & $\begin{array}{l}-0.32^{+} \\
(1.71)\end{array}$ & & & & & \\
\hline $\begin{array}{l}\text { Part-time empl* } \\
\text { Usual hours }\end{array}$ & & & & $\begin{array}{l}0.81^{*} \\
(1.86)\end{array}$ & & & & & \\
\hline$U E \operatorname{gap}_{i, t}$ & & & & $\begin{array}{l}-0.001^{-} \\
(1.47)\end{array}$ & & $\begin{array}{r}-0.002^{-} \\
(1.49)\end{array}$ & $\begin{array}{c}-0.003^{+} \\
(1.83)\end{array}$ & $\begin{array}{l}-0.02^{*} \\
(2.15)\end{array}$ & $\begin{array}{r}-0.004^{+} \\
(1.91)\end{array}$ \\
\hline Sweden*UE gap $_{i, t}$ & & & & $\begin{array}{l}-0.02^{* *} \\
(2.66)\end{array}$ & & & & & \\
\hline Sickness benefit ${ }_{i, t}$ & & & & & $\begin{array}{l}0.02^{* *} \\
(3.41)\end{array}$ & $\begin{array}{l}0.03^{* *} \\
(2.66)\end{array}$ & $\begin{array}{l}0.04^{*} \\
(3.16)\end{array}$ & & $\begin{array}{l}0.01^{*} \\
(2.13\end{array}$ \\
\hline Sweden*Sick. benefit $t_{i, t}$ & & & & & $\begin{array}{l}0.21^{* *} \\
(3.18)\end{array}$ & & & & \\
\hline UE benefit $t_{i, t}$ & & & & & & $\begin{array}{l}0.003 \\
(0.53)\end{array}$ & & & $\begin{array}{l}-0.02^{* *} \\
(2.59)\end{array}$ \\
\hline Employer sick pay $y_{i, t}$ & & & & & & & $\begin{array}{l}-0.01^{+} \\
(1.74)\end{array}$ & & \\
\hline Union density $_{i, t}$ & & & & & & & & $\begin{array}{l}0.02^{*} \\
(2.07)\end{array}$ & \\
\hline Union $*$ Empl. sick pay $y_{i, t}$ & & & & & & & & $\begin{array}{r}0.0002^{-} \\
(1.53)\end{array}$ & \\
\hline Union $^{*} U E$ benefit $t_{i, t}$ & & & & & & & & & $\begin{array}{c}0.001^{* *} \\
(2.87)\end{array}$ \\
\hline constant & $\begin{array}{l}0.03^{-} \\
(1.57)\end{array}$ & $\begin{array}{r}-0.002 \\
(0.19)\end{array}$ & $\begin{array}{l}0.003 \\
(0.31)\end{array}$ & $\begin{array}{l}-0.009 \\
(0.90)\end{array}$ & $\begin{array}{c}0.01 \\
(1.05)\end{array}$ & $\begin{array}{c}0.02 \\
(1.34)\end{array}$ & $\begin{array}{l}0.02^{+} \\
(1.85)\end{array}$ & $\begin{array}{l}0.01 \\
(0.94)\end{array}$ & $\begin{array}{l}0.01^{-} \\
(1.51)\end{array}$ \\
\hline $\mathrm{AR}(2)-p$-values & 0.48 & 0.22 & 0.28 & 0.96 & 0.49 & 0.26 & 0.22 & 0.36 & 0.23 \\
\hline Obs. (groups) & $248(36)$ & $437(36)$ & $437(36)$ & $454(36)$ & $320(26)$ & $320(26)$ & $320(26)$ & $264(30)$ & $220(26)$ \\
\hline
\end{tabular}




\section{Summary of Results}

As expected, labor force characteristics are important in determining sickness absence. In particular, good health-proxied here by life expectancy-and low labor force participation reduce absence. Age shows no significant independent impact, suggesting that its effect might already be captured by participation. The significant coefficient for the gender dummy indicates that females are more likely to be on sick leave than males.

Working time arrangements have a significant impact. In particular, while more flexibilitymeasured by the share of part-time employment and flexible working time arrangementshelps to reduce sickness absence, longer usual hours of work tend to increase it. The results also suggest that more flexible work arrangements reduce the impact of long working hours on attendance. The estimated impact of usual hours worked appears to be close to the findings by Barmby and others (2004) for the United Kingdom, where the estimated coefficient on usual hours is 0.16. A major conclusion of Barmby and others (2004) is that sickness absence is relatively more sensitive to the determinants that measure contractual arrangements than to individual characteristics.

Sickness absence is pro-cyclical, but only in some countries. The unemployment gap enters the regressions with a negative sign, in line with the hypothesis that market conditions exert a disciplining effect on absence. This effect is however reduced by employment protectionproxied here by union density - as shown by the negative interaction term. These results can hardly be generalized. When the unemployment gap is interacted with country dummies, the coefficient estimate is negative and significant only for Sweden.

Sickness benefits have a robust and positive impact on absence. The coefficient for sickness benefits, as measured by the after-tax replacement rate, is estimated to be in a range between 0.02 and 0.06. However, a significant and large interaction term of Sweden's fixed effect with sickness benefit indicates that the impact for Sweden is substantially stronger than the cross-country average, more than twice as large. It can be estimated that a 10-percentage point reduction of the net replacement rate in Sweden would yield a 1-to-2 percentage point drop in the absence rate.

Absence declines when employers bear larger costs of sickness insurance. Measured by the product of the cash benefit replacement rate with the period that falls under the employers' responsibility, these costs have a clear negative impact. This result suggests that higher costs, by changing employers' incentives and behavior, may indeed reduce absence.

Characteristics of labor market institutions affect the absence rate in different ways, both directly and through their interaction with the business cycle and sickness insurance provisions. Employment protection has a significant positive impact on absence rates both directly and when interacted with the unemployment gap, which is consistent with the evidence provided by Ichino and Riphan (2004) for Italy. The negative impact of employers' sick pay provisions is somewhat reduced by employment protection, suggesting that the latter 
may reduce the employer's ability to enforce better work attendance. The results for unemployment benefits, while suggesting a possible role, are not robust enough to lead to definite conclusions.

\section{ConClusions ANd Policy IMPlications}

The evidence presented in the paper suggests that sickness absence is very high at least in four countries: the Netherlands, Sweden, Norway, and the United Kingdom. In these countries, between 4 and 6 percent of employees are absent on a given day, with losses in terms of forgone output that are likely to be substantial. Owing to their generous public insurance systems, the Netherlands, Sweden, and Norway bear significant costs in terms of public finances. Containing sickness absence would help prevent the erosion of labor supply stemming from demographics and working time reductions.

High sickness absence reflects, to some extent, high labor force participation, particularly of women and older people. Countries with high sickness absence have generally high participation rates, to which both the traditional Nordic emphasis on social inclusion and the market-oriented approach followed by the United Kingdom may have contributed. Going forward, as populations age, maintaining high employment rates will be increasingly challenging and containing the erosion of labor supply even more urgent. With large changes in the composition of the labor force, the overall impact of these changes on sickness absence is difficult to predict.

The high level of sickness absence, however, is not a necessary price for high participation. The results presented in this paper, as well as the evidence provided by the literature, indicate the existence of a significant incentive problem owing to the generosity and the leniency of the public insurance schemes in the Netherlands, Sweden, and Norway. Streamlining the systems in these countries appears necessary to improve labor supply incentives. Our results show that a modest reduction of the replacement rate would yield a sizable reduction in sickness absence, particularly in Sweden. The benefits of a well-designed reform are likely to be substantial, of the order of 0.5 to 1 percent of GDP for Sweden (Andersen and Molander, 2003). A comprehensive reform of sickness insurance should consider the link with other components of the social insurance system. The Swedish example shows that the interaction of sickness insurance with unemployment insurance creates a perverse incentive for the unemployed to be listed as sick. By harmonizing the replacement rates between the two systems in 2003, the government has largely reduced this incentive. A review of the link between sickness insurance and disability pensions and their role in promoting early retirement is also advisable.

A shift of part of the insurance costs to employers is advisable. The paper shows that higher costs are likely to produce a response by employers, which will ultimately help to reduce absence. This effect, however, is likely to be smaller, the higher is the level of employment protection. To be most effective, the cost shift must affect the employer incentives via an increase in the marginal cost of absence. If the incentive is diluted, and the shift translates into a mere increase in labor costs, negative effects on employment are more likely to result. 
One way to achieve a more efficient impact would be to leave more room for workers and employers to determine the level of protection, which could be achieved only by a substantial reduction in the replacement rate of the public insurance scheme. The Netherlands has undertaken a major reform in 1996, shifting all costs to employers, and has seen absence declining in the last few years.

Encouraging flexible work arrangements is likely to pay off. The results presented here suggest that policies promoting shorter working hours may not be inconsistent with the objective of reducing absence. High sickness absence in the United Kingdom, say, seems to be explained mainly by its comparatively long working hours. These policies, however, may still lead to a net reduction of hours worked, even if the accompanying decrease in sickness absence would partly offset their effect. Encouraging the diffusion of flexible work arrangements, which are shown to substantially reduce absence, may be a better policy option. 


\section{DATA AND DESCRIPTIVE StATISTICS}

Table A.1. List of Countries and Data Availability

\begin{tabular}{llc}
\hline & Country & Working time data \\
\hline 1. & Belgium & $1983-2003$ \\
2. & Denmark & $1983-2003$ \\
3. & Germany & $1983-2003$ \\
4. & Greece & $1983-2003$ \\
5. & Spain & $1987-2003$ \\
6. & France & $1983-2003$ \\
7. & Ireland & $1983-2003$ \\
8. & Italy & $1983-2003$ \\
9. & Luxembourg & $1983-2002$ \\
10. & Netherlands & $1983-2003$ \\
11. & Austria & $1995-2003$ \\
12. & Portugal & $1986-2003$ \\
13. & Finland & $1995-2003$ \\
14. & Sweden & $1995-2003$ \\
15. & United Kingdom & $1983-2003$ \\
16. & Iceland & $1995-2002$ \\
17. & Norway & $1995-2003$ \\
18. & Switzerland & $1996-2003$ \\
\hline Note: & denotes missing data for Germany (1984), Italy \\
(1992), and the Netherlands (1984, 1986).
\end{tabular}


Table A.2. List of Variables, Definitions, and Sources

\begin{tabular}{|c|c|c|}
\hline Variable & Definition & Source \\
\hline Absence rate & $\begin{array}{l}\text { Share of persons absent due to sickness in percent of total } \\
\text { employed, full-time employees only; includes persons } \\
\text { who worked at least } 1 \text { hour and persons in employment } \\
\text { who did not work at all during the reference week }\end{array}$ & Eurostat, NewCronos \\
\hline $\begin{array}{l}\text { Labor force participation } \\
\text { rate (LFPR) }\end{array}$ & $\begin{array}{l}\text { Defined as the ratio of the labor force (employed and } \\
\text { unemployed) to the working age population (of age 15- } \\
64) \text {, in percent }\end{array}$ & ILO, KILM (2003) \\
\hline Age structure & $\begin{array}{l}\text { Share of labor force of age 55-64 in labor force of age } 15- \\
64, \text { in percent }\end{array}$ & ILO, KILM (2003) \\
\hline Life expectancy & Life expectancy at birth, in number of years & ILO, KILM (2003) \\
\hline Usual hours & $\begin{array}{l}\text { Average number of usual hours worked during the } \\
\text { reference week, full-time employees only }\end{array}$ & Eurostat, NewCronos \\
\hline Part-time employment & $\begin{array}{l}\text { Share of part-time employment in total employed, in } \\
\text { percent }\end{array}$ & ILO, KILM (2003) \\
\hline Flexible hours & $\begin{array}{l}\text { Share of persons absent due to flexible working time } \\
\text { arrangement in percent of total employed, full-time } \\
\text { employees only who worked at least } 1 \text { hour }\end{array}$ & Eurostat, NewCronos \\
\hline Unemployment (UE) gap & $\begin{array}{l}\text { Deviation of unemployment rate from (linear) trend } \\
\text { unemployment rate, in percent trend unemployment rate }\end{array}$ & $\begin{array}{l}\text { ILO, KILM (2003); } \\
\text { OECD, Economic } \\
\text { Outlook }\end{array}$ \\
\hline Sickness benefit & Sickness benefit net replacement rate & Scruggs (2004) \\
\hline $\begin{array}{l}\text { Index of sickness } \\
\text { insurance system } \\
\text { generosity }\end{array}$ & $\begin{array}{l}\text { Weighted sum of four main components of sickness } \\
\text { insurance system (net replacement rate, qualification } \\
\text { period, duration, waiting period) in turn weighted by } \\
\text { general coverage rate of sickness insurance }\end{array}$ & Scruggs (2004) \\
\hline $\begin{array}{l}\text { Unemployment (UE) } \\
\text { benefit }\end{array}$ & Unemployment benefit net replacement rate & Scruggs (2004) \\
\hline $\begin{array}{l}\text { Index of unemployment } \\
\text { insurance system } \\
\text { generosity }\end{array}$ & $\begin{array}{l}\text { Weighted sum of four main components of } \\
\text { unemployment insurance system (net replacement rate, } \\
\text { qualification period, duration, waiting period) in turn } \\
\text { weighted by general coverage rate of unemployment } \\
\text { insurance }\end{array}$ & Scruggs (2004) \\
\hline Union density & Net union density & WEO (2004) \\
\hline $\begin{array}{l}\text { Employment protection } \\
\text { (EP) }\end{array}$ & Index of employment protection & WEO (2004) \\
\hline Employer sick pay & $\begin{array}{l}\text { Sick pay paid by employers, calculated as number of days } \\
\text { of sick pay multiplied by replacement rate }\end{array}$ & $\begin{array}{c}\text { U.S. SSA } \\
\text { (various issues) }\end{array}$ \\
\hline Gender & $\begin{array}{l}\text { Dummy variable }=1 \text { for male employees, }=0 \text { for female } \\
\text { employees }\end{array}$ & \\
\hline
\end{tabular}


Table A.3. Descriptive Statistics

\begin{tabular}{lrrrrr}
\hline Variable & Mean & Median & Std. Dev. & Min & Max \\
\hline Sickness absence rate & 2.75 & 2.28 & 1.71 & 0.09 & 10.26 \\
LFPR & 68.56 & 74.5 & 14.49 & 36.2 & 90.1 \\
Age structure & 9.39 & 9.6 & 3.12 & 2.0 & 17.8 \\
Life expectancy & 76.79 & 76.8 & 1.47 & 73.5 & 79.8 \\
Usual hours & 39.9 & 39.7 & 2.23 & 36.2 & 52.1 \\
Part-time employment & 14.14 & 12.65 & 6.39 & 4.2 & 34.5 \\
Flexible hours & 2.4 & 0.76 & 3.74 & 0.01 & 18.42 \\
Unemployment gap & 1.07 & 1.90 & 20.83 & -50.0 & 58.5 \\
Sickness benefit & 68.69 & 74.91 & 23.3 & 20.04 & 111.0 \\
Unemployment benefit & 9.14 & 63.0 & 20.56 & 1.98 & 86.49 \\
Union density & 41.22 & 40.0 & 20.26 & 10.0 & 90.0 \\
Employment protection & 1.25 & 1.32 & 0.5 & 0.35 & 2.0 \\
Employer sick pay & 10.89 & 5.0 & 14.02 & 0.0 & 65.0 \\
\hline
\end{tabular}

Notes: LFPR=Labor force participation rate. See Table A.2 for the definitions and sources of the variables. 
Table A.4. Cross-Correlations Between Variables of Model

\begin{tabular}{|c|c|c|c|c|c|c|c|c|c|c|c|}
\hline & LFPR & $\begin{array}{r}\text { Age } \\
\text { Struc- } \\
\text { ture }\end{array}$ & $\begin{array}{r}\text { Life } \\
\text { Expec- } \\
\text { tancy }\end{array}$ & $\begin{array}{l}\text { Usual } \\
\text { Hours }\end{array}$ & $\begin{array}{r}\text { Part- } \\
\text { time } \\
\text { Employ } \\
\text {-ment }\end{array}$ & $\begin{array}{r}\text { Flexible } \\
\text { Hours }\end{array}$ & UE Gap & $\begin{array}{r}\text { Sickness } \\
\text { Benefit }\end{array}$ & $\begin{array}{r}\text { UE } \\
\text { Benefit }\end{array}$ & $\begin{array}{l}\text { Union } \\
\text { Density }\end{array}$ & $\begin{array}{r}\text { Empl. } \\
\text { Protec- } \\
\text { tion }\end{array}$ \\
\hline \multicolumn{12}{|l|}{ LFPR } \\
\hline Age structure & $0.59^{*}$ & & & & & & & & & & \\
\hline Life expectancy & $0.15^{*}$ & $0.13^{*}$ & & & & & & & & & \\
\hline Usual hours & $0.58^{*}$ & $0.51^{*}$ & 0.06 & & & & & & & & \\
\hline Part-time employment & $0.34^{*}$ & $0.09^{*}$ & $0.32^{*}$ & $0.14^{*}$ & & & & & & & \\
\hline Flexible hours & $0.32^{*}$ & $0.26^{*}$ & 0.09 & $0.25^{*}$ & $0.48^{*}$ & & & & & & \\
\hline UE gap & -0.02 & -0.05 & $0.11^{*}$ & -0.006 & 0.02 & -0.05 & & & & & \\
\hline Sickness benefit & 0.06 & $0.09^{*}$ & $0.22^{*}$ & $-0.41^{*}$ & -0.05 & $-0.46^{*}$ & -0.01 & & & & \\
\hline UE benefit & $0.18^{*}$ & $0.30^{*}$ & $0.21^{*}$ & $-0.23^{*}$ & $0.25^{*}$ & $-0.32^{*}$ & -0.01 & $0.58^{*}$ & & & \\
\hline Union density & $0.27^{*}$ & $0.21^{*}$ & -0.09 & $-0.14^{*}$ & 0.02 & $0.25^{*}$ & 0.01 & $0.13^{*}$ & 0.06 & & \\
\hline $\mathrm{EP}$ & $-0.13^{*}$ & -0.08 & -0.002 & $-0.25^{*}$ & $-0.45^{*}$ & $-0.58^{*}$ & 0.10 & $0.66^{*}$ & $0.16^{*}$ & $-0.10^{*}$ & \\
\hline Employer sick pay & 0.04 & $-0.09^{*}$ & 0.06 & -0.06 & $0.19^{*}$ & 0.09 & -0.01 & $0.24^{*}$ & 0.08 & $0.12^{*}$ & 0.002 \\
\hline
\end{tabular}

Notes: ${ }^{*}=$ significant at 5\% significance level; LFPR=Labor force participation rate; UE=Unemployment; EP=Employment protection. See Table

A. 2 for the definitions and sources of the variables. 


\section{SICKNESS BENEFITS IN EUROPE}

\section{Table A.5. Comparative Table on Sickness Cash Benefits (as of 01.01.2004)}

\begin{tabular}{|c|c|}
\hline \multicolumn{2}{|l|}{ BELGIUM } \\
\hline Basic principles & $\begin{array}{l}\text { Compulsory social insurance scheme for employees with earnings-related benefits. } \\
\text { Maintenance of salary paid by the employer during a limited period. }\end{array}$ \\
\hline \multicolumn{2}{|l|}{ A. Conditions } \\
\hline 1. Proof of incapacity & $\begin{array}{l}\text { To have provided the sickness fund doctor with a "notice of cessation of work" } \\
\text { within } 2 \text { days. }\end{array}$ \\
\hline 2. Qualifying period & $\begin{array}{l}\text { - Period of work and membership required: } 6 \text { months, in which } 120 \text { days of work } \\
\text { or assimilated periods (unemployment, legal holidays, etc.). } \\
\text { - Proof of payment of minimum amount of contributions. } \\
\text { To have ceased all activities because of reduction of earning capacity of at least } \\
66 \% \text {. }\end{array}$ \\
\hline B. Waiting period & $\begin{array}{l}\text { One working day. No waiting period: If the insured person has been unemployed for } \\
\text { at least } 9 \text { days within the } 21 \text { days prior to the incapacity for work; if incapacity is due } \\
\text { to pregnancy or confinement; for unemployed persons in the employment of the } \\
\text { public authorities; if the worker has been in contact with someone suffering from an } \\
\text { infectious disease. }\end{array}$ \\
\hline \multicolumn{2}{|r|}{ 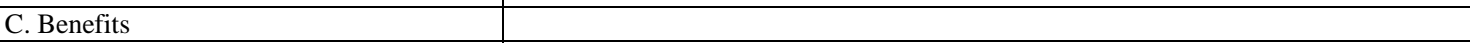 } \\
\hline 1. Benefit paid by employers & $\begin{array}{l}\text { Manual workers: } \\
-\quad \text { during the first } 7 \text { days of incapacity for work: } 100 \% \text { of earnings; } \\
\text { - } \quad \text { from 8th to 14th day of incapacity: } 60 \% \text { of upper earnings limit and a } \\
\text { supplementary allowance (indemnité complémentaire/aanvullende } \\
\text { tegemoetkoming); } \\
\text { from 15th to 30th day of incapacity: supplementary allowance (indemnité } \\
\text { complémentaire/aanvullende tegemoetkoming). } \\
\text { White-collar workers: } 100 \% \text { of earnings during a period of one month. }\end{array}$ \\
\hline \multicolumn{2}{|l|}{ 2. Benefits of social protection } \\
\hline - Amount & $\begin{array}{l}\text { The compensation insurance starts when the guaranteed salary period paid by the } \\
\text { employer is over. This Means after two weeks of disability for workers and one } \\
\text { month for employees. } \\
\text { General rule: } 60 \% \text { of earnings. Exception: since the } 31 \text { st day of disability for co- } \\
\text { habitant recipients: } 55 \% \text { of earnings. Ceiling taken into account for the } \\
\text { compensation: } € 101.2117 \text { per day. }\end{array}$ \\
\hline - Duration & Maximum of one year (period of "primary incapacity for work"). \\
\hline - Special condition for unemployed & $\begin{array}{l}\text { The incapacity benefit during the first six months cannot be less than the } \\
\text { unemployment benefit that an unemployed person would have received. }\end{array}$ \\
\hline D. Taxation of benefits & Benefits are subject to taxation \\
\hline \multicolumn{2}{|l|}{ DENMARK } \\
\hline Basic principles & $\begin{array}{l}\text { Universal protection scheme for the active population (employees and self-employed) } \\
\text { with earnings-related benefits. }\end{array}$ \\
\hline \multicolumn{2}{|l|}{ A. Conditions } \\
\hline 1. Proof of incapacity & $\begin{array}{l}\text { Benefits paid by the employer: The employer can pretend a written } \\
\text { Declaration from the ill person stating his sickness as from the second day and a } \\
\text { medical certificate as from the fourth day of illness. Benefits paid by the } \\
\text { municipality: A medical bulletin - form delivered by the municipality - must be } \\
\text { introduced at the latest one week after the first day of sickness or one week after the } \\
\text { last employer payment. }\end{array}$ \\
\hline 2. Qualifying period & $\begin{array}{l}\text { Salaried workers: } \\
\text { Benefits paid by the employer: Minimum working period of } 74 \text { hours during the } 8 \\
\text { weeks immediately preceding the sickness. } \\
\text { Benefits paid by the municipality: } \\
\text { Period of work of at least } 120 \text { hours in } 13 \text { weeks immediately preceding illness, or } \\
\text { persons who have just completed a vocational training course for a period of at least } \\
18 \text { months and persons doing a paid work placement as part of a vocational training } \\
\text { course, or unemployed entitled to benefits from unemployment insurance or similar } \\
\text { benefits (anti-unemployment measures); persons in a "flexible job" with a private or } \\
\text { public employer. }\end{array}$ \\
\hline
\end{tabular}


Table A.5. (continued) Comparative Table on Sickness Cash Benefits (as of 01.01.2004)

\begin{tabular}{|c|c|}
\hline & $\begin{array}{l}\text { Self-employed: } \\
\text { - Professional activity on a certain scale for a duration of at least } 6 \text { months within the } \\
\text { last } 12 \text { month period, of which one month immediately precedes the illness. } \\
\text { - Voluntary insurance for self-employed and helping spouse: } 6 \text { months period (except } \\
\text { work injury and persons who have recently set themselves up as self employed } \\
\text { persons and become member of the insurance within three months after the } \\
\text { termination of their salaried activity). }\end{array}$ \\
\hline B. Waiting period & $\begin{array}{l}\text { Salaried workers: No waiting period. } \\
\text { Self-employed: } 2 \text { weeks. For this period, voluntary insurance for self-employed and } \\
\text { helping spouse that allows a benefit since the } 3 \text { rd sickness day, or, with payment of a } \\
\text { premium supplement, beginning the first day of sickness. }\end{array}$ \\
\hline \multicolumn{2}{|l|}{ C. Benefits } \\
\hline 1. Benefit paid by employers & $\begin{array}{l}\text { Collective agreements provide for the continued payment of wages and salaries in the } \\
\text { case of sickness for certain groups of employees. In this case the employers are } \\
\text { entitled to receive the sickness cash benefit (sygedagpenge) of the employees. }\end{array}$ \\
\hline \multicolumn{2}{|l|}{ 2. Benefits of social protection } \\
\hline - Amount & $\begin{array}{l}\text { Salaried workers: Sickness cash benefit (sygedagpenge) calculated upon the basis of } \\
\text { the hourly wage of the worker (contributions to Labour Market Fund, } \\
\text { Arbejdsmarkedsfonden, deducted), with a maximum of DKK } 3,113 \text { (€418) per week } \\
\text { or DKK } 84.14 \text { ( } € 11 \text { ) per hour ( } 37 \text { hours per week), and upon the number of hours of } \\
\text { work. Period to be covered by the employer: } 2 \text { weeks. } \\
\text { Self-employed: Sickness cash benefit calculated on the basis of the earnings from the } \\
\text { occupational activity of the self-employed person, with the same maximum as } \\
\text { mentioned above. The self-employed persons who have taken out a voluntary } \\
\text { insurance (see above), are entitled to at least } 2 / 3 \text { of the maximum amount }\end{array}$ \\
\hline - Duration & $\begin{array}{l}52 \text { weeks in } 18 \text { months; pensioners or people who have reached the age of } 65 \text { ( } 67 \text { for } \\
\text { those who had reached the age of } 60 \text { on } 1 \text { st July } 1999) \text { not more than } 13 \text { weeks in a } \\
12 \text {-month period. Not included: the first two weeks of a period of sickness. Benefits } \\
\text { can be paid for a longer period under certain conditions, for example when beginning } \\
\text { a probable re-education process, when the municipality starts the analysis of an } \\
\text { application for disability pension or in the case of employment injury. Similarly when } \\
\text { an ill person work capacity seems recoverable. If necessary, benefits can be paid for a } \\
\text { longer period up to } 26 \text { weeks, in order to test the ill person work capacity. The local } \\
\text { authorities assume the control task. After an } 8 \text {-week period of absence due to illness } \\
\text { - and every } 8 \text { weeks - the local authorities assess the possible steps to take. At the } \\
\text { first control and at the latest after } 6 \text { months of illness during a period of } 12 \text { months, } \\
\text { the local authorities will draw up a future assistance plan to be proposed to the ill } \\
\text { person. If the work capacity is not recovered, the local authorities must start the } \\
\text { procedure leading to an invalidity pension. }\end{array}$ \\
\hline - Special condition for unemployed & $\begin{array}{l}\text { The unemployed and persons in receipt of various anti unemployment benefits are } \\
\text { entitled to the same amount they would have received ad they not fallen ill, with the } \\
\text { maximum amount indicated above. }\end{array}$ \\
\hline D. Taxation of benefits & Benefits are subject to taxation. \\
\hline \multicolumn{2}{|l|}{ GERMANY } \\
\hline Basic principles & $\begin{array}{l}\text { Compulsory social insurance scheme for employees and categories of persons } \\
\text { assimilated thereto up to a certain income limit with earnings-related benefits. } \\
\text { Possible voluntary insurance in the case of income exceeding the ceiling. } \\
\text { Maintenance of salary paid by the employer. }\end{array}$ \\
\hline \multicolumn{2}{|l|}{ A. Conditions } \\
\hline 1. Proof of incapacity & Incapacity for work certified by doctor. \\
\hline 2. Qualifying period & Neither work period nor qualifying period required. \\
\hline B. Waiting period & $\begin{array}{l}\text { No waiting period if incapacity with entitlement to statutory sick pay under labour } \\
\text { law or if sickness is due to a work injury or a professional disease or if hospital } \\
\text { treatment is required. }\end{array}$ \\
\hline \multicolumn{2}{|r|}{ 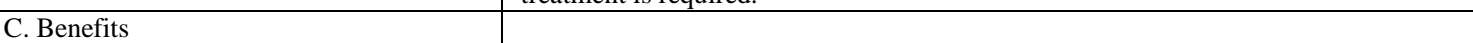 } \\
\hline 1. Benefit paid by employers & Continuation of payment: Manual and white-collar workers: 6 weeks. \\
\hline \multicolumn{2}{|l|}{ 2. Benefits of social protection } \\
\hline - Amount & $\begin{array}{l}\text { Sickness benefit (Krankengeld): } 70 \% \text { of the normal salary but not exceeding } 90 \% \text { of } \\
\text { the net salary. Normal salary (Regelentgelt): Wages and income from work, normally } \\
\text { received (during last } 3 \text { months), insofar as subject to contribution. After one year } \\
\text { adjustment as for pensions }\end{array}$ \\
\hline - Duration & $\begin{array}{l}\text { Sickness benefit (Krankengeld) for the same illness, limited to } 78 \text { weeks over a 3- } \\
\text { year period. }\end{array}$ \\
\hline
\end{tabular}


Table A.5. (continued) Comparative Table on Sickness Cash Benefits (as of 01.01.2004)

\begin{tabular}{|c|c|}
\hline - Special condition for unemployed & $\begin{array}{l}\text { Initially continued wage payment paid by the labour office, then sickness benefits } \\
\text { paid by the sickness insurance fund to the amount of the previous wage replacement } \\
\text { benefit paid by the labour office. }\end{array}$ \\
\hline D. Taxation of benefits & $\begin{array}{l}\text { The continuation of employer's payments is subject to taxation. Sickness insurance } \\
\text { benefits are not subject to taxation (but subject to progression). }\end{array}$ \\
\hline \multicolumn{2}{|l|}{ GREECE } \\
\hline Basic principles & $\begin{array}{l}\text { Compulsory social insurance scheme for employees with contribution-related } \\
\text { benefits. }\end{array}$ \\
\hline \multicolumn{2}{|r|}{ D } \\
\hline 1. Proof of incapacity & Incapacity for work certified by the Institute's doctor. \\
\hline 2. Qualifying period & $\begin{array}{l}100 \text { days of work subject to contributions during the previous year or the } 12 \text { first } \\
\text { months of the } 15 \text { preceding the illness (duration of benefit: } 182 \text { days). } \\
300 \text { days subject to contributions during the } 2 \text { years, or } 27 \text { months of the } 30 \text {, } \\
\text { preceding the illness (duration of benefit: } 360 \text { days). } \\
1,500 \text { days of insurance during the last } 5 \text { years preceding the incapacity for work due } \\
\text { to the same illness (duration of benefit: } 720 \text { days). }\end{array}$ \\
\hline B. Waiting period & 3 days. \\
\hline \multicolumn{2}{|l|}{ C. Benefits } \\
\hline 1. Benefit paid by employers & No continuation of payment of wage in case of sickness. \\
\hline \multicolumn{2}{|l|}{ 2. Benefits of social protection } \\
\hline - Amount & $\begin{array}{l}\text { For the first } 15 \text { days: The total ceiling For sickness benefit (EPIDOMA ASENEIAS) } \\
\text { plus supplement for dependants (max. } 4 \text { ) is } € 13.53 \text { per day (daily wage assumed for } \\
\text { 3rd insurance category). After } 15 \text { days: The total ceiling for benefits plus } \\
\text { supplements for dependants (max. 4) is } € 24.87 \text { per day (daily wage assumed for 8th } \\
\text { insurance category). }\end{array}$ \\
\hline - Duration & $\begin{array}{l}\text { Duration of benefits depending on the length of the period of contributions: } 182,360 \\
\text { or } 720 \text { days. (See above "conditions"). }\end{array}$ \\
\hline - Special condition for unemployed & No special conditions. \\
\hline D. Taxation of benefits & $\begin{array}{l}\text { Benefits are generally subject to taxation. Certain exemptions for persons crippled in } \\
\text { war, war victims and their families, blind persons and persons suffering from } \\
\text { paraplegia. }\end{array}$ \\
\hline \multicolumn{2}{|l|}{ SPAIN } \\
\hline Basic principles & $\begin{array}{l}\text { Compulsory social insurance scheme for employees and assimilated groups with } \\
\text { contribution-related benefits for temporary incapacity (Incapacidad temporal). }\end{array}$ \\
\hline \multicolumn{2}{|l|}{ A. Conditions } \\
\hline 1. Proof of incapacity & $\begin{array}{l}\text { Doctor's certificate confirming unfitness for work to be sent on 4th day of absence } \\
\text { and received by employing firm within } 5 \text { days following its dispatch. }\end{array}$ \\
\hline 2. Qualifying period & $\begin{array}{l}\text { Contributions paid for } 180 \text { days during } 5 \text { years immediately preceding illness (with } \\
\text { the exception of accidents). }\end{array}$ \\
\hline B. Waiting period & 3 days. \\
\hline \multicolumn{2}{|l|}{ C. Benefits } \\
\hline 1. Benefit paid by employers & $\begin{array}{l}\text { No continuation of payment of salaries but from the } 4 \text { th to the } 15 \text { th day of sickness, } \\
\text { the benefit ( } 60 \% \text { of the salary) is payable by the employer. }\end{array}$ \\
\hline \multicolumn{2}{|l|}{ 2. Benefits of social protection } \\
\hline - Amount & 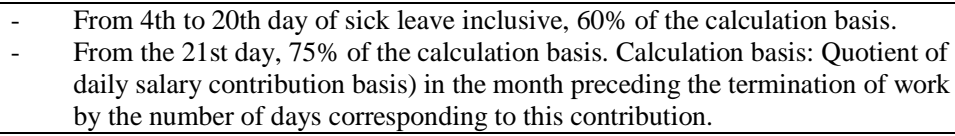 \\
\hline - Duration & $\begin{array}{l}12 \text { months with possibility of extension for a further } 6 \text { months where there is deemed } \\
\text { to be a chance of the beneficiary once again being fit for work. }\end{array}$ \\
\hline - Special condition for unemployed & No special conditions. \\
\hline D. Taxation of benefits & Benefits are subject to taxation. \\
\hline \multicolumn{2}{|l|}{ FranCE } \\
\hline Basic principles & Compulsory social insurance scheme for employees with earnings-related benefits. \\
\hline \multicolumn{2}{|r|}{$e^{T}$} \\
\hline 1. Proof of incapacity & $\begin{array}{l}\text { Rest prescription by the doctor stating the working incapacity. Use of the working } \\
\text { interruption sheet, precising the probable incapacity duration. }\end{array}$ \\
\hline
\end{tabular}


Table A.5. (continued) Comparative Table on Sickness Cash Benefits (as of 01.01.2004)

\begin{tabular}{|c|c|}
\hline 2. Qualifying period & $\begin{array}{l}\text { The insured must have paid a minimum of contributions on the basis of } \mathrm{n} \text { times the } \\
\text { minimum wage (salaire minimum interprofessionnel de croissance, SMIC) of } € 7.19 \\
\text { per hour on } \\
01.07 .2003 \text {. } \\
\text { - For the first } 6 \text { months: } 1,015 \text { SMIC in the 6preceding months. } \\
\text { - After } 6 \text { months and having been registered for a minimum of } 12 \text { months since } \\
\text { having stopped working: } 2,030 \text { SMIC in the } 12 \text { previous months, including } \\
1,015 \text { SMIC in the first } 6 \text { months. In both cases, claims may also be investigated } \\
\text { on the basis of the number of hours worked. }\end{array}$ \\
\hline B. Waiting period & 3 days. \\
\hline \multicolumn{2}{|l|}{ C. Benefits } \\
\hline 1. Benefit paid by employers & $\begin{array}{l}\text { The payment of the part of lost earnings above the sickness cash benefits (indemnités } \\
\text { journalières deMaladie) depends on collective agreement or on the monthly } \\
\text { payments agreement. }\end{array}$ \\
\hline \multicolumn{2}{|l|}{ 2. Benefits of social protection } \\
\hline - Amount & $\begin{array}{l}\text { - } 50 \% \text { of daily earnings, in a limit of } 1 / 720 \text { th of the annual ceiling, maximum } \\
€ 41.26 \text {. } \\
66.66 \% \text { of daily earnings with a limit of } 1 / 540 \text { th of the annual ceiling from } 31^{\text {st }} \\
\text { day for beneficiaries with } 3 \text { children, maximum } € 55.02 \text {. } \\
51.49 \% \text { from } 7 \text { th month of drawing benefits without interruption. Maximum } \\
\text { 1/700th of annual ceiling: } € 42.44 \text {, minimum } € 7.94 \text {. For persons with } 3 \\
\text { dependant children: } 68.66 \% \text {. Maximum } 1 / 525 \text { th of annual ceiling: } € 56.59, \\
\text { minimum: } € 10.58 \text {. }\end{array}$ \\
\hline - Duration & $\begin{array}{l}\text { Normally } 12 \text { months ( } 360 \text { days) per period of } 3 \text { consecutive years, but until end of } \\
\text { 36th month for "protracted sickness". }\end{array}$ \\
\hline - Special condition for unemployed & No special conditions. \\
\hline D. Taxation of benefits & Benefits are subject to taxation after deduction of $10 \%$ and $20 \%$. \\
\hline \multicolumn{2}{|l|}{ IRELAND } \\
\hline Basic principles & $\begin{array}{l}\text { Compulsory social insurance scheme for employees with flat-rate Disability Benefit } \\
\text { and supplements for dependants. }\end{array}$ \\
\hline \multicolumn{2}{|l|}{ A. Conditions } \\
\hline 1. Proof of incapacity & Certification by insured person's doctor. \\
\hline 2. Qualifying period & $\begin{array}{l}\text { - } 39 \text { weekly contributions paid since first starting employment and } \\
\text { - } 39 \text { weekly contributions paid or credited during the contribution year preceding } \\
\text { the benefit year, of which a minimum of } 13 \text { must be paid contributions. The } \\
\text { latter requirement may be satisfied by contributions paid in some other } \\
\text { contribution years, or } \\
26 \text { weekly contributions paid in each of the two contribution years preceding } \\
\text { the benefit year. }\end{array}$ \\
\hline B. Waiting period & 3 days. \\
\hline \multicolumn{2}{|l|}{ C. Benefits } \\
\hline 1. Benefit paid by employers & Not applicable. \\
\hline \multicolumn{2}{|l|}{ 2. Benefits of social protection } \\
\hline - Amount & $\begin{array}{l}\text { Disability Benefit: } € 134.80 \text { per week. Family supplements: Adult dependant: } € 89.80 \\
\text { per week. Each child dependant: } € 16.80 \text { per week. }\end{array}$ \\
\hline - Duration & $\begin{array}{l}\text { Unlimited if the claimant has paid } 260 \text { weekly contributions. Limited to } 52 \text { weeks if } \\
\text { between } 39 \text { and } 260 \text { weekly contributions paid. }\end{array}$ \\
\hline - Special condition for unemployed & No special conditions. \\
\hline D. Taxation of benefits & $\begin{array}{l}\text { Benefits are fully liable to taxation after } 6 \text { weeks payment in any tax year (including } \\
\text { supplement for adult dependants but excluding supplements for child dependants). }\end{array}$ \\
\hline \multicolumn{2}{|l|}{ ICELAND } \\
\hline Basic principles & $\begin{array}{l}\text { Tax financed system with flat-rate benefits for all actively employed who do not } \\
\text { receive salaries during sickness. }\end{array}$ \\
\hline \multicolumn{2}{|r|}{ (1) } \\
\hline 1. Proof of incapacity & Incapacity for work due to sickness certified by a doctor. \\
\hline 2. Qualifying period & 6 months residency for new residents. Generally 2 months work prior to illness. \\
\hline B. Waiting period & 14 days. \\
\hline \multicolumn{2}{|l|}{ C. Benefits } \\
\hline 1. Benefit paid by employers & $\begin{array}{l}\text { Collective agreements provide for the continued payment of wages and salaries for a } \\
\text { certain period depending on agreements, in which case sickness cash benefits } \\
\text { (sjúkradagpeningar) are not granted, until wages have ceased. }\end{array}$ \\
\hline
\end{tabular}


Table A.5. (continued) Comparative Table on Sickness Cash Benefits (as of 01.01.2004)

\begin{tabular}{|c|c|}
\hline \multicolumn{2}{|l|}{ 2. Benefits of social protection } \\
\hline - Amount & $\begin{array}{l}\text { Per diem sickness cash benefits (sjúkradagpeningar) for persons who have to give up } \\
\text { full-time gainful employment ISK } 846 \text { ( } € 9.47 \text { ). } \\
\text { Daily amount for persons who have to give up less than full-time but at least half- } \\
\text { time employment ISK } 423 \text { (€4.73). }\end{array}$ \\
\hline - Duration & 52 weeks in any one period of 24 months. \\
\hline - Special condition for unemployed & Same amount and conditions. Unemployment benefit ceases for the same period. \\
\hline D. Taxation of benefits & Benefits are liable to taxation. \\
\hline \multicolumn{2}{|l|}{ ITALY } \\
\hline Basic principles & $\begin{array}{l}\text { Compulsory social insurance scheme for manual workers with earnings-related } \\
\text { benefits. } \\
\text { Maintenance of payment of salary by the employer for white-collar employees. }\end{array}$ \\
\hline \multicolumn{2}{|r|}{ 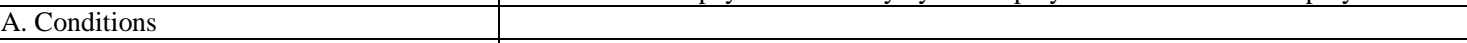 } \\
\hline 1. Proof of incapacity & $\begin{array}{l}\text { The employee must produce a medical Certificate to his employer, who Can decide } \\
\text { to proceed to any control. }\end{array}$ \\
\hline 2. Qualifying period & $\begin{array}{l}\text { No work period nor qualifying period } \\
\text { Required. }\end{array}$ \\
\hline B. Waiting period & 3 days. None for TB. \\
\hline \multicolumn{2}{|l|}{ C. Benefits } \\
\hline 1. Benefit paid by employers & The employer is obligated by law to Continue paying wages for at least 3 Months. \\
\hline \multicolumn{2}{|l|}{ 2. Benefits of social protection } \\
\hline - Amount & $\begin{array}{l}\text { Without hospitalisation: } 50 \% \text {. From } 21 \text { st day } 66.66 \% \text { (earnings taken as basis: Real } \\
\text { earnings). With hospitalisation: Allowance is reduced to } 2 / 5 \text { for insured without } \\
\text { dependants. Tuberculosis: Daily benefit during treatment (indennità giornaliera di } \\
\text { cura): Insured person: As the sickness benefit for } 180 \text { days, then } € 10.54 \text {; members of } \\
\text { the family: } € 5.27 \text {. Daily post-sanatorium benefit (indennità giornaliera } \\
\text { postsanatoriale): Insured person: } € 17.56 \text {; members of the family: } € 8.78 \text {. Cure } \\
\text { allowance (assegno di cura postsostentamento): } € 70.80 \text { per month. The allowance is } \\
\text { granted after the post-sanatorium treatment and is completed where earnings capacity } \\
\text { is reduced by at least } 50 \% \text {. }\end{array}$ \\
\hline - Duration & $\begin{array}{l}\text { Maximum of } 6 \text { months ( } 180 \text { days) per year. For TB: No limit during treatment; } \\
\text { maximum of } 2 \text { years for post-sanatorium allowance; } 2 \text { years for the treatment } \\
\text { allowance (renewable every } 2 \text { years). }\end{array}$ \\
\hline - Special condition for unemployed & No special conditions. \\
\hline D. Taxation of benefits & Benefits are subject to taxation. \\
\hline \multicolumn{2}{|l|}{ LUXEMBOURG } \\
\hline Basic principles & $\begin{array}{l}\text { Compulsory social insurance scheme for all active population (employees and self- } \\
\text { employed) with earnings-related benefits. }\end{array}$ \\
\hline \multicolumn{2}{|l|}{ A. Conditions } \\
\hline 1. Proof of incapacity & Medical certificate is requested from the second day. \\
\hline 2. Qualifying period & No work period nor qualifying period required. \\
\hline B. Waiting period & No waiting period. \\
\hline \multicolumn{2}{|l|}{ C. Benefits } \\
\hline 1. Benefit paid by employers & $\begin{array}{l}\text { In the case of sickness, white-collar employees in the private sector continue to } \\
\text { receive pay by the employer for the month in which the disease occurs and for the } \\
\text { following } 3 \text { months. No continuation of payment for manual workers. }\end{array}$ \\
\hline \multicolumn{2}{|l|}{ 2. Benefits of social protection } \\
\hline - Amount & $\begin{array}{l}\text { The full salary which the insured person would have earned if he had continued to } \\
\text { work. }\end{array}$ \\
\hline - Duration & $\begin{array}{l}\text { Maximum: } 52 \text { weeks. Payment ends if an invalidity pension (pension d'invalidité) is } \\
\text { granted. }\end{array}$ \\
\hline - Special condition for unemployed & $\begin{array}{l}\text { The unemployed keep profiting from the unemployment benefit (indemnité de } \\
\text { chômage). }\end{array}$ \\
\hline D. Taxation of benefits & Benefits are subject to taxation. \\
\hline
\end{tabular}


Table A.5. (continued) Comparative Table on Sickness Cash Benefits (as of 01.01.2004)

\begin{tabular}{|c|c|}
\hline \multicolumn{2}{|l|}{ NETHERLANDS } \\
\hline Basic principles & $\begin{array}{l}\text { The Dutch Civil Code stipulates since } 1996 \text { that employers must } \\
\text { continue to pay out the salary of sick employees for the first year of sickness. } \\
\text { The Sickness Benefit Act (Ziektewet, } Z W \text { ) will continue to exist as a "safety net" for } \\
\text { employees who do not or no longer have an employer, and in a few special } \\
\text { circumstances. }\end{array}$ \\
\hline \multicolumn{2}{|r|}{ ( } \\
\hline 1. Proof of incapacity & $\begin{array}{l}\text { When reporting sick, one must comply with the following rules: } \\
-\quad \text { stay at home until the implementation institution Inspector has called in to see, } \\
\text { - } \\
\text { - } \quad \text { llow the Inspector visiting the patient at home, } \\
\text { - } \quad \text { facilitate his own recovery, } \\
\text { - } \quad \text { keep ones appointment with the medical Insurance Office of the } \\
\text { Implementation Institution. }\end{array}$ \\
\hline 2. Qualifying period & No work period nor qualifying period required. \\
\hline B. Waiting period & No waiting period. \\
\hline \multicolumn{2}{|l|}{ C. Benefits } \\
\hline 1. Benefit paid by employers & $\begin{array}{l}\text { Continued payment of } 70 \% \text { of wages for } 52 \text { weeks. Maximum daily wage } \\
\text { considered: } € 167 \text {. With the minister's approval this percentage can be increased by } \\
\text { the industrial boards. }\end{array}$ \\
\hline \multicolumn{2}{|l|}{ 2. Benefits of social protection } \\
\hline - Amount & $\begin{array}{l}\text { Sickness Benefit Act (Ziektewet, } Z W \text { ) as safety net (see "Basic principles"): } 70 \% \text { of } \\
\text { the daily wage. Maximum daily wage considered: } € 167 \text {. }\end{array}$ \\
\hline - Duration & 104 weeks. \\
\hline - Special condition for unemployed & No special conditions. \\
\hline D. Taxation of benefits & Benefits are subject to taxation. \\
\hline \multicolumn{2}{|l|}{ NORWAY } \\
\hline Basic principles & $\begin{array}{l}\text { Compulsory scheme with full compensation for the loss of income for workers, } \\
\text { reduced compensation for the self-employed. }\end{array}$ \\
\hline \multicolumn{2}{|r|}{ 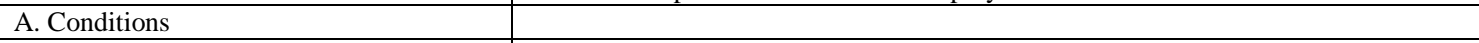 } \\
\hline 1. Proof of incapacity & $\begin{array}{l}\text { Incapacity for work due to sickness certified by a doctor. Employees have a right to } \\
\text { give their employer notice of incapacity due to sickness for up to } 3 \text { calendar days at a } \\
\text { time. Restrictions in case of frequent recurrence. Has the employer entered an } \\
\text { Inclusive } \\
\text { Workplace Agreement (IA-avtale) with the National Insurance Service, the employee } \\
\text { may give notice of incapacity for up to } 8 \text { calendar days at a time, up to a maximum of } \\
24 \text { days a year }\end{array}$ \\
\hline 2. Qualifying period & Generally four weeks of work. \\
\hline B. Waiting period & $\begin{array}{l}\text { No waiting period for employees. } 16 \text { days for freelancers and self-employed. A } \\
\text { voluntary insurance supplement to cover the waiting period is available to both } \\
\text { groups. }\end{array}$ \\
\hline \multicolumn{2}{|r|}{ (n) } \\
\hline 1. Benefit paid by employers & $\begin{array}{l}\text { The employer pays sickness cash Benefit (sykepenger) for up to } 16 \text { calendar days. } \\
\text { Where the employer continues to pay the salary beyond this period, the sickness cash } \\
\text { benefit is paid to the employer. }\end{array}$ \\
\hline \multicolumn{2}{|l|}{ 2. Benefits of social protection } \\
\hline - Amount & $\begin{array}{l}100 \% \text { of the salary from the } 1 \text { st day for employees, } 100 \% \text { of the income basis from } \\
\text { the } 17 \text { th day for freelancers and } 65 \% \text { from the } 17 \text { th day for self-employed. A } \\
\text { voluntary insurance supplement to } \\
\text { cover a rate of } 100 \% \text { is available to the self-employed. A general maximum annual } \\
\text { income basis of } 6 \text { times the Basic Amount (Grunnbelopet) applies i.e. NOK } 341,166 \\
(€ 40,646) \text {. }\end{array}$ \\
\hline - Duration & 260 days (52 weeks) for employees, 248 days for freelancers and self-employed. \\
\hline - Special condition for unemployed & $\begin{array}{l}\text { The unemployment benefit (dagpenger under arbeidsloshet) per week is taken as } \\
\text { income basis for sickness cash benefit (sykepenger). }\end{array}$ \\
\hline D. Taxation of benefits & Benefits are subject to taxation. \\
\hline \multicolumn{2}{|l|}{ Austria } \\
\hline Basic principles & $\begin{array}{l}\text { Compulsory social insurance scheme for employees with earnings-related benefits. } \\
\text { Maintenance of payment of salary by the employer. }\end{array}$ \\
\hline
\end{tabular}


Table A.5. (continued) Comparative Table on Sickness Cash Benefits (as of 01.01.2004)

\begin{tabular}{|c|c|}
\hline A. Conditions & \\
\hline 1. Proof of incapacity & Incapacity for work due to sickness certified by a doctor. \\
\hline 2. Qualifying period & No qualifying period. \\
\hline B. Waiting period & $\begin{array}{l}\text { Sickness benefit (Krankengeld): } 3 \text { days. Commencement of benefit only from date } \\
\text { notification if unfitness for work has not been reported with one week. }\end{array}$ \\
\hline \multicolumn{2}{|l|}{ C. Benefits } \\
\hline 1. Benefit paid by employers & $\begin{array}{l}\text { Continued payment of wages for workers and salaried between } 6 \text { and } 12 \text { weeks, } \\
\text { following the length of Service. At the end of this period They are entitled to the } \\
\text { payment of half their salaries for a period of } 4 \text { weeks. No sickness benefit } \\
\text { (Krankengeld) during } 100 \% \text { continued payment of wages, half of sickness benefit for } \\
\text { the period in which } 50 \% \text { of the salaries are paid. }\end{array}$ \\
\hline \multicolumn{2}{|l|}{ 2. Benefits of social protection } \\
\hline - Amount & $\begin{array}{l}\text { Sickness benefit (Krankengeld): } 50 \% \text { of gross wage or salary, } 60 \% \text { from } 43 \text { rd day of } \\
\text { illness. Ceiling: } € 3,450 \text { per month. For persons with earnings below the marginal } \\
\text { earnings threshold for compulsory insurance who are voluntary insured, the sickness } \\
\text { benefit is } € 113.57 \text {. }\end{array}$ \\
\hline - Duration & $\begin{array}{l}\text { Sickness benefit (Krankengeld): Generally the legally stipulated minimum time } \\
\text { period is } 52 \text { weeks. According to the insurance funds' statute, however, the sickness } \\
\text { benefit can be extended to } 78 \text { weeks. }\end{array}$ \\
\hline - Special condition for unemployed & No special conditions. \\
\hline D. Taxation of benefits & Continued payment of wages and sickness benefit are both subject to taxation. \\
\hline \multicolumn{2}{|l|}{ Portugal } \\
\hline Basic principles & $\begin{array}{l}\text { Compulsory social insurance scheme for employees (voluntary scheme for self- } \\
\text { employed) with benefits related to the registered earnings. }\end{array}$ \\
\hline \multicolumn{2}{|l|}{ A. Conditions } \\
\hline 1. Proof of incapacity & Medical certificate. \\
\hline 2. Qualifying period & $\begin{array}{l}6 \text { months membership with registered salary and } 12 \text { days salary registered during the } \\
4 \text { months prior to the one preceding the day of incapacity. }\end{array}$ \\
\hline B. Waiting period & $\begin{array}{l}3 \text { days per period of absence owing to incapacity. None in the event of } \\
\text { hospitalisation, after maternity or in case of tuberculosis. }\end{array}$ \\
\hline \multicolumn{2}{|r|}{ 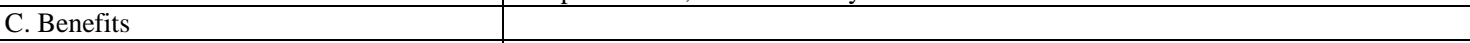 } \\
\hline 1. Benefit paid by employers & No legal regulations for the continuation of payment of salaries. \\
\hline \multicolumn{2}{|l|}{ 2. Benefits of social protection } \\
\hline - Amount & $\begin{array}{l}\text { Daily benefit: } \\
\text { - } 65 \% \text { of average daily wage for } 6 \text { months preceding the } 2 \text { months in which the } \\
\text { illness began. } \\
\text { - } 70 \% \text { of this average wage after a period of incapacity of more than } 365 \text { days } \\
\text { without interruption. } \\
\text { In the event of tuberculosis: } 80 \% \text { of average wage or } 100 \% \text { in case of } \\
\text { hospitalisation or if insured has } 2 \text { or more dependants. Minimum amount: } 30 \% \\
\text { of the minimum wage or the average earning if it is lower than this percentage. }\end{array}$ \\
\hline - Duration & $\begin{array}{l}\text { Maximum 1,095 days (then, possibly, invalidity). In the event of tuberculosis: } \\
\text { Unlimited. }\end{array}$ \\
\hline - Special condition for unemployed & No special conditions. \\
\hline D. Taxation of benefits & Benefits are not subject to taxation. \\
\hline \multicolumn{2}{|l|}{ SWITZERLAND } \\
\hline Basic principles & $\begin{array}{l}\text { Optional insurance which provides benefits in the event of sickness, accident } \\
\text { (if not covered by an accident insurance) and maternity. An insurance obligation may } \\
\text { result from an individual employment contract, a standard employment contract, } \\
\text { or a collective labour agreement. In this case, the daily allowance insurance } \\
\text { (Taggeldversicherung/assurance d'indemnités journalières)may be taken out as a } \\
\text { collective insurance contract. }\end{array}$ \\
\hline \multicolumn{2}{|r|}{ (2) } \\
\hline 1. Proof of incapacity & Incapacity to work of at least $50 \%$, certified by a doctor. \\
\hline 2. Qualifying period & $\begin{array}{l}\text { The insurers may exclude from the insurance, by making a reservation, illnesses } \\
\text { existing at the time of admission. Reservations end after } 5 \text { years at the latest. Special } \\
\text { rules on changing insurer. }\end{array}$ \\
\hline B. Waiting period & $\begin{array}{l}\text { Unless otherwise agreed, the right to benefits begins on the 3rd day following the } \\
\text { beginning of the illness. }\end{array}$ \\
\hline
\end{tabular}


Table A.5. (continued) Comparative Table on Sickness Cash Benefits (as of 01.01.2004)

\begin{tabular}{|c|c|}
\hline C. Benefits & \\
\hline 1. Benefit paid by employers & $\begin{array}{l}\text { Under the terms of Book } \mathrm{V} \text { of the Civil Code, the employers are required to continue } \\
\text { to pay the salary for a limited period in the event of prevention from working due to } \\
\text { an illness or maternity. The duration is } 3 \text { weeks during the 1st year of service. } \\
\text { Thereafter a longer period is fixed on an "equitable" basis. Collective labour } \\
\text { agreements often contain more favourable conditions. }\end{array}$ \\
\hline \multicolumn{2}{|l|}{ 2. Benefits of social protection } \\
\hline - Amount & $\begin{array}{l}\text { The insurer agrees with the insured person the amount of daily allowances } \\
\text { (Taggeld/indemnités journalières) insured. }\end{array}$ \\
\hline - Duration & At least 720 days in a period of 900 consecutive days. \\
\hline - Special condition for unemployed & $\begin{array}{l}\text { Unemployed persons with work incapacity above } 50 \% \text { receive full daily allowances; } \\
\text { those with work incapacity between } 25 \text { and } 50 \% \text { receive half daily allowances. } \\
\text { Unemployed persons can request the transformation of their insurance accompanied } \\
\text { by revised premiums. }\end{array}$ \\
\hline D. Taxation of benefits & Benefits are subject to taxation. \\
\hline \multicolumn{2}{|l|}{ FINLAND } \\
\hline Basic principles & $\begin{array}{l}\text { Compulsory sickness insurance scheme for all inhabitants (based on residency) with } \\
\text { earnings-related benefits and means-tested benefits. }\end{array}$ \\
\hline \multicolumn{2}{|r|}{ 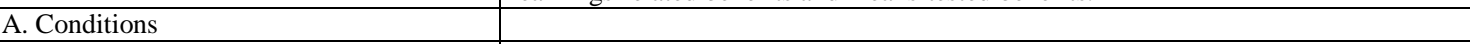 } \\
\hline 1. Proof of incapacity & Incapacity for work due to sickness certified by a doctor. \\
\hline 2. Qualifying period & No work period nor qualifying period required. \\
\hline B. Waiting period & 9 days (excluding Sundays) following the day on which the illness begins. \\
\hline \multicolumn{2}{|r|}{ 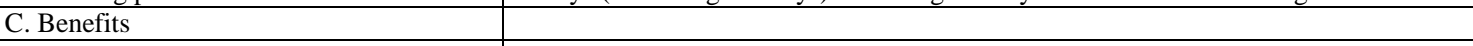 } \\
\hline 1. Benefit paid by employers & No legal regulations for the continuation of payment of salaries. \\
\hline \multicolumn{2}{|l|}{ 2. Benefits of social protection } \\
\hline - Amount & $\begin{array}{l}\text { Daily amounts dependent on annual earnings: } \\
\text { - } \quad \text { earnings under } € 1,026 \text { : payable only if sick leave lasts more than } 55 \text { days with } \\
\text { limitations: } € 11.45 \text { per week day. } \\
\text { - } \quad € 1,027-€ 26,720: 70 \% \text { of } 1 / 300 \text { earnings; } \\
-\quad \text { earnings } € 26,721-€ 41,110: € 62.35 \text { plus } 40 \% \text { of } 1 / 300 \text { of earnings exceeding } \\
\quad € 26,720 ; \\
-\quad \text { above } € 41,110: € 81.53 \text { plus } 25 \% \text { of } 1 / 300 \text { of earnings exceeding } € 41,109 .\end{array}$ \\
\hline - Duration & For the same illness, limited to 300 days (excluding Sundays) over a 2- year period. \\
\hline - Special condition for unemployed & $\begin{array}{l}\text { If an unemployed person received Unemployment benefits for at least } 4 \text { Months, the } \\
\text { sickness benefit will amount to at least } 86 \% \text { of the unemployment benefit. }\end{array}$ \\
\hline D. Taxation of benefits & Benefits are subject to taxation. \\
\hline \multicolumn{2}{|l|}{ SWEDEN } \\
\hline Basic principles & $\begin{array}{l}\text { Compulsory sickness insurance scheme for the active population (employees and } \\
\text { self-employed) with earnings-related benefits. } \\
\text { Maintenance of payment of salary } \\
\text { by the employer. }\end{array}$ \\
\hline \multicolumn{2}{|l|}{ A. Conditions } \\
\hline 1. Proof of incapacity & $\begin{array}{l}\text { A doctor must certify incapacity for work due to illness as from the } 8^{\text {th }} \text { day of illness. } \\
\text { The illness must be reported to the employer/the local social insurance office } \\
\text { (försäkringskassa) from the first day of absence. }\end{array}$ \\
\hline 2. Qualifying period & Neither work period nor qualifying period required. \\
\hline B. Waiting period & $\begin{array}{l}\text { Employees: One day waiting period. Self-employed: } \\
\text { May choose waiting-period of } 3 \text { or } 30 \text { days. }\end{array}$ \\
\hline \multicolumn{2}{|l|}{ C. Benefits } \\
\hline 1. Benefit paid by employers & $\begin{array}{l}\text { The employer pays sick pay (sjuklön) as from the } 2 \text { nd up to the } 21 \text { st day of illness at } \\
80 \% \text { of wages. }\end{array}$ \\
\hline \multicolumn{2}{|l|}{ 2. Benefits of social protection } \\
\hline - Amount & $\begin{array}{l}77.6 \% \text { of the income qualifying for } 7 \text { sickness cash benefit (sjukpenning). The social } \\
\text { insurance office (försäkringskassa) pays sickness cash benefit as from the 22nd day } \\
\text { in a period of illness. }\end{array}$ \\
\hline - Duration & $\begin{array}{l}\text { There is no formal limitation but the sickness cash benefit (sjukpenning) may be } \\
\text { converted into a disability pension (sjukbidrag/förtidspension) if the illness continues } \\
\text { for an extended period of time. }\end{array}$ \\
\hline - Special condition for unemployed & $\begin{array}{l}\text { Unemployed persons are entitled to sickness cash benefit (sjukpenning) with the } \\
\text { same amount they received before the last employment ended, as long as they are } \\
\text { actively looking for a job. }\end{array}$ \\
\hline
\end{tabular}


Table A.5. (concluded) Comparative Table on Sickness Cash Benefits (as of 01.01.2004)

\begin{tabular}{|c|c|}
\hline D. Taxation of benefits & Benefits are subject to taxation. \\
\hline \multicolumn{2}{|l|}{ UNITED KINGDOM } \\
\hline Basic principles & $\begin{array}{l}\text { Statutory Sick Pay (SSP) paid by the employer. } \\
\text { Compulsory social insurance scheme for employees, which has flat-rate benefits. }\end{array}$ \\
\hline \multicolumn{2}{|l|}{ A. Conditions } \\
\hline 1. Proof of incapacity & $\begin{array}{l}\text { Incapable of carrying out normal occupation ("own occupation test"). Usually based } \\
\text { on medical certificates from family doctor. The "personal capability assessment" } \\
\text { applies after } 28 \text { weeks of incapacity, or from first week if insufficient recent } \\
\text { employment upon which to base "own occupation test". }\end{array}$ \\
\hline 2. Qualifying period & $\begin{array}{l}\text { Statutory Sick Pay: Employees' earnings before sickness must have reached the } \\
\text { Lower Earnings Limit }(L E L) \text { for National Insurance contribution purposes. Short- } \\
\text { term incapacity benefit: Must have paid sufficient contributions in any one of the } \\
\text { three tax years before the year of the claim, and have been paid or been credited with } \\
\text { sufficient contributions in } 2 \text { relevant tax years; normally the } 2 \text { preceding the year of } \\
\text { the claim. Employees have to satisfy the contribution conditions where they claim } \\
\text { short-term incapacity benefit on cessation of Statutory Sick Pay. }\end{array}$ \\
\hline B. Waiting period & 3 days. \\
\hline \multicolumn{2}{|l|}{ C. Benefits } \\
\hline 1. Benefit paid by employers & $\begin{array}{l}\text { Statutory Sick Pay: paid by employer in case of illness lasting at least } 4 \text { consecutive } \\
\text { days up to a maximum of } 28 \text { weeks. Standard rate of GBP } 64.35 \text { (€91) per week. } \\
\text { Earnings less than GBP } 77(€ 109) \text { : No benefit. No additions for dependants. }\end{array}$ \\
\hline \multicolumn{2}{|l|}{ 2. Benefits of social protection } \\
\hline - Amount & $\begin{array}{l}\text { Short-term incapacity benefit: Paid at two rates: lower rate of GBP } 54.40(€ 77) \text { per } \\
\text { week for first } 28 \text { weeks; higher rate of GBP } 64.35 \text { ( } € 91) \text { thereafter. If over pension } \\
\text { age, up to GBP } 72.15 \text { ( } € 102) \text { per week. Additions: Spouse aged } 60 \text { or over or adult } \\
\text { caring for dependent child GBP } 33.65 \text { ( } € 48 \text { ) or if over pension age GBP } 41.50 \text { ( } € 59 \text { ). } \\
\text { Child dependency increase with higher rate benefit, or from first day if over pension } \\
\text { age: GBP } 9.65 \text { ( } € 14 \text { ) for first child, GBP } 11.35 \text { ( } € 16) \text { for each other. Not available for } \\
\text { claims from April } 2003 \text {. }\end{array}$ \\
\hline - Duration & $\begin{array}{l}\text { Short-term incapacity benefit: } 52 \text { weeks maximum in a period of incapacity for work; } \\
\text { lower rate payable for first } 28 \text { weeks, followed by higher rate from week } 29 \text {. Then } \\
\text { replaced by long-term incapacity benefit. }\end{array}$ \\
\hline - Special condition for unemployed & No special conditions. \\
\hline D. Taxation of benefits & $\begin{array}{l}\text { Statutory Sick Pay and Higher rate short-term incapacity benefit are subject to } \\
\text { taxation. Lower rate short-term incapacity Benefit is not subject to taxation. }\end{array}$ \\
\hline
\end{tabular}

Source: MISSOC (2004). 


\section{REFERENCES}

Allen, S.G., 1981., "An Empirical Model of Work Attendance," Review of Economics and Statistics, Vol. 63, No. 1, pp. 77-87.

Andersen, T., and P. Molander, eds., 2003a, Alternatives for Welfare Policy (Cambridge, United Kingdom: Cambridge University Press).

,2003b, "Policy Options for Reforming the Welfare State," in Andersen and Molander, eds. (2003a).

Anderson, T.W., and C. Hsiao, 1982, "Formulation and Estimation of Dynamic Panel Models Using Panel Data,” Journal of Econometrics, Vol. 18, pp. 47-82.

Andrén, D., 2001a, "Short-term Absenteeism Due to Sickness: The Swedish Experience, 1986-1991," Working Paper in Economics No. 46 (Department of Economics, Göteborg University).

, 2001b, "Long-term Absenteeism Due to Sickness: The Swedish Experience, 19861991," Working Paper in Economics No. 47 (Department of Economics, Göteborg University).

,2003, "Sickness-related Absenteeism and Economic Incentives in Sweden: A History of Reforms," CESifo DICE Report 3/2003 (Munich: CESifo Group).

Arai, M., and P. Skogman Thoursie, 2001, "Incentive and Selection in Cyclical Absenteeism," FIEF Working Paper Series No. 167 (Stockholm: Trade Union Institute for Economic Research).

Arellano, M., and S. Bond, 1991, "Some Tests of Specification for Panel Data: Monte Carlo Evidence and an Application to Employment Equations," Review of Economic Studies, Vol. 58, No. 2, pp. 277-297.

Audas, R., and J. Goddard, 2001, “Absenteeism, Seasonality, and the Business Cycle," Journal of Economics and Business, Vol. 53, pp. 405-419.

Barmby, T.A., Ercolani, M.G., and J.G.Treble, 2002, "Sickness Absence: An International Comparison," Economic Journal, Vol 112, pp. F315-F331.

2004, “Sickness Absence in the UK: 1984-2002," Swedish Economic Policy Review, Vol. 11, forthcoming. Available via the Internet: http://www.swan.ac.uk/welmerc/Sickness\%20and\%20absence.pdf 
Bergendorff, S., Berggren, S., Cohen Birman, M., Nyberg, K. Palmer, E., Skogman Thoursie, P., and J. Soderberg, 2004, "Sickness Absence in Europe - A Comparative Study," Social Insurance Studies No. 2, Swedish National Insurance Board, forthcoming.

Blundell, R., and S. Bond, 1998, "Initial Conditions and Moment Restrictions in Dynamic Panel Data Models," Journal of Econometrics, Vol. 87, pp. 115-143.

Bonato, L., and L. Lusinyan, 2004, "Sickness Absence: Sweden in an International Perspective," in Sweden: Selected Issues, IMF Country Report No. 04/245 (Washington: International Monetary Fund).

Brown, S., and J.G. Sessions, 1996, “The Economics of Absence: Theory and Evidence," Journal of Economic Surveys, Vol. 10, No. 1, pp. 23-53.

Chaudhury, M., and I. Ng, 1992, "Absenteeism Predictors: Least Squares, Rank Regression, and Model Selection Results", Canadian Journal of Economics, Vol. 25, No. 3, pp. 615634.

De Jong, P., and M. Lindeboom, 2004, "Privatisation of Sickness Insurance: Evidence from the Netherlands," Swedish Economic Policy Review, Vol. 11, forthcoming. Available via the Internet: http://www.ape.nl/pdf/De Jong \%20Lindeboom 4.pdf

Drago, R., and M. Wooden, 1992, “The Determinants of Labor Absence: Economic Factors and Workgroup Norms Across Countries," Industrial and Labor Relations Review, Vol. 45, No. 4, pp. 764-778.

Drukker, D. M., 2003, “Testing for Serial Correlation in Linear Panel-Data Models,” Stata Journal, Vol. 3, No. 2, pp. 168-177.

Dunn, L.F., and S.A.Youngblood, 1986, "Absenteeism as a Mechanism for Approaching an Optimal Labor Market Equilibrium: An Empirical Study," Review of Economics and Statistics, Vol. 68, No. 4, pp. 668-674.

European Foundation for the Improvement of Living and Working Conditions, European Industrial Relations Observatory (EIRO), various issues. Available via the Internet: http://www.eiro.eurofound.eu.int

Henrekson, M., and M. Persson, 2004, "The Effects on Sick Leave of Changes in the Sickness Insurance System,” Journal of Labor Economics, Vol. 22, No. 1, pp. 87-113.

Houseman, S.N., and K.G. Abraham, 1993, "Labor Adjustment Under Different Institutional Structures: A Case of Germany and the United States," NBER Working Paper No. 4548 (Cambridge, Massachusetts: National Bureau of Economic Research). 
Johansson, P., and M. Palme, 1996, "Do Economic Incentives Affect Work Absence? Empirical Evidence Using Swedish Micro Data," Journal of Public Economics, Vol. 59, pp. 195-218.

, 2002, "Assessing the Effect of Public Policy on Worker Absenteeism," Journal of Human Resources, Vol. 37, pp. 381-409.

Ichino, A., and R.T. Riphahn, 2004, "The Effect of Employment Protection on Worker Effort. A Comparison of Absenteeism During and After Probation," Journal of the European Economic Association (forthcoming). Available via the Internet: http://www.iue.it/Personal/Ichino/short44.pdf

Im, K.S., Pesaran, M.H., and Y. Shin, 1997, “Testing for Unit Roots in Heterogeneous Panels," Discussion Paper December (Cambridge, United Kingdom: University of Cambridge, Department of Applied Economics). Available via the Internet at: http://www.econ.cam.ac.uk/faculty/pesaran/lm.pdf

International Labour Organization (ILO), 2003, Key Indicators of the Labour Markets (KILM) (Geneva). Available on CD-ROM.

International Monetary Fund, 2004, World Economic Outlook, April 2004: A Survey by the Staff of the International Monetary Fund, World Economic and Financial Surveys (Washington).

Judson R.A., and A.L. Owen, 1999, "Estimating Dynamic Panel Data Models: A Guide for Macroeconomists," Economics Letters, Vol. 65, pp. 9-15.

Kaivanto, K., 1997, “An Alternative Model of Pro-Cyclical Absenteeism,” Economics Letters, Vol. 54, pp. 29-34.

Kiviet, J.F., 1995, “On Bias, Inconsistency, and Efficiency of Various Estimators in Dynamic Panel Data Models," Journal of Econometrics, Vol. 68, pp. 53-78.

Larsson, L., 2002, "Sick of Being Unemployed? Interactions Between Unemployment and Sickness Insurance in Sweden," IFAU Working Paper 2002:6 (Uppsala, Sweden: Institute for Labour Market Policy Evaluation). , 2004, "Harmonizing Unemployment and Sickness Insurance: Why (Not)?" IFAU Working Paper 2004:8 (Uppsala, Sweden: Institute for Labour Market Policy Evaluation).

Leigh, J.P., 1985, "The Effects of Unemployment and the Business Cycle on Absenteeism," Journal of Economics and Business, Vol. 37, pp. 159-170. 
Levin, A., and C. Lin, 1992, "Unit Root Tests in Panel Data: Asymptotic and Finite-Sample Properties," Discussion Paper 92-23 (La Jolla, California: University of California, San Diego).

Lindbeck, A., 1977, “The Swedish Experiment,” Journal of Economic Literature, Vol. 35, No. 3, pp. 1273-319.

Lusinyan, L., 2003, "Dynamic Panel Data Models in Macroeconomic Applications: The Role of Cross-Sectional Dependence," (unpublished; Florence: European University Institute).

Mutual Information System on Social Protection in the EU Member States and the EEA (MISSOC), 2004, "Social Protection in the Member States of the European Union, of the European Economic Area and in Switzerland, Situation on 1 January 2004," European Commission, Directorate-General for Employment and Social Affairs (Brussels). Available via the Internet: http://europa.eu.int/comm/employment social/missoc/missoc2004 en.pdf

Organization for Economic Cooperation and Development (OECD), 2003, The Sources of Economic Growth in OECD Countries (Paris).

Palme, M., and I. Svensson, 2003, "Pathways to Retirement and Retirement Incentives in Sweden," in Andersen and Molander, eds. (2003a).

Prescott, E.C., 2004, "Why Do Americans Work So Much More Than Europeans?" NBER Working Paper No. 10316 (Cambridge, Massachusetts: National Bureau of Economic Research).

Scruggs, L., 2004, Comparative Welfare Entitlements Data Set (Storrs, Connecticut: University of Connecticut).

Shapiro, C., and J. E. Stiglitz, 1984, "Equilibrium Unemployment as a Worker Discipline Device," American Economic Review, Vol. 74, No. 3, pp. 433-444.

Skogman Thoursie, P., 2002, "Reporting Sick: Are Sporting Events Contagious?” Research Paper in Economics 2002:4 (Stockholm, Sweden: Stockholm University, Department of Economics).

United States Social Security Administration (U.S. SSA), Social Security Programs Throughout the World (Washington), various issues.

Wooldridge, J. M., 2002, Econometric Analysis of Cross Section and Panel Data (Cambridge, Massachusetts: MIT Press). 